\title{
Electric field effects on proteins - Novel perspectives on food and potential health implications
}

\author{
Rui M. Rodrigues, Zita Avelar, Luís Machado, Ricardo N. Pereira*, António A. Vicente \\ CEB - Centre of Biological Engineering, University of Minho, 4710-057 Braga, Portugal
}

\section{A R T I C L E I N F O}

\section{Keywords:}

Protein structure

Hydrogels

Allergenicity

Gastrointestinal digestion

Innovative processing

Bioactive

\begin{abstract}
A B S T R A C T
Electric fields (EF) technologies have been establishing a solid position in emergent food processing and have seen as serious alternatives to traditional thermal processing. During the last decades, research has been devoted to elucidation of technological and safety issues but also fundamental aspects related with interaction of electric fields (EF) with important macromolecules, such as proteins. Proteins are building blocks for the development of functional networks that can encompass health benefits (i.e. nutritional and bioactive properties) but may be also linked with adverse effects such as neurodegenerative diseases (amyloid fibrils) and immunological responses. The biological function of a protein depends on its tridimensional structure/conformation, and latest research evidences that EF can promote disturbances on protein conformation, change their unfolding mechanisms, aggregation and interaction patterns. This review aims at bringing together these recent findings as well as providing novel perspectives about how EF can shape the behavior of proteins towards the development of innovative foods, aiming at consumers' health and wellbeing.
\end{abstract}

\section{Introduction}

Proteins play a critical role in food and nutrition, primarily as source of amino acids and secondly by providing many different functional and technological characteristics, thus contributing in quality, stability and organoleptic properties of foods. Proteins are polymers composed by chains of amino acids that may vary in composition, length and number. Furthermore, proteins' native 3-dimensional structure is associated with a specific fold resulting from numerous interactions between the amino acids within the protein and the physicochemical environment (Creighton, 1993). Due to the large number of stabilizing and destabilizing interactions within the protein fold that have found at least a local minimum, a protein conformation is inherently unstable (Onuchic, Luthey-Schulten, \& Wolynes, 1997). All of this results in a large variety of structures, biological properties and functionalities with intrinsic structural dynamics and high responsiveness to environmental factors.

The structure/function relationship in proteins is a well-documented and prevalent topic in biotechnology. It is generally accepted that the specific conformation of a protein will impact its biological activities, such as catalytic, ligand binding, regulatory, but also allergenicity and techno-functional properties - e.g. transport and release of bioactives, stabilization of foams and emulsions or interactions with each other to aggregate or create networks (Bryant \& McClements, 1998; Mirmoghtadaie, Shojaee Aliabadi, \& Hosseini, 2016). Food proteins undergo a series of processing steps, either on the production process, extraction and cooking, or during more intricate processes of food biotechnology, involving transformation and functionalization. These processing steps have as main objectives to stabilize foods and food ingredients, biological inactivation (such as reduction or elimination of microbial and enzymatic activity) and/or to change or promote certain organoleptic and nutritional/nutraceutical properties in foods (Aryee, Agyei, \& Udenigwe, 2018; Vanga, Singh, \& Raghavan, 2017). In order to fulfil these specific objectives, several unit operations are established, often involving high levels of physical stress - i.e. mechanical, pressure, thermal or electrically-induced stress - which may cause changes in protein structure and conformation, resulting in changes on their properties and functionality.

During the last decades, major attention has been given to the processing impact in food quality, resulting in improved processing strategies and development of new technologies (Jia, Liu, \& Ma, 2019). Aiming at replacing the costly and highly aggressive thermal processes, emerging technologies such as high hydrostatic pressure processing, sonication, or electric fields (EF) processing are gaining attention due to their potential to improve foodstuff quality and functionality (De Vries

\footnotetext{
* Corresponding author.

E-mail address: rpereira@deb.uminho.pt (R.N. Pereira).
} 
et al., 2018; Priyadarshini, Rajauria, O’Donnell, \& Tiwari, 2018; Roohinejad, Koubaa, Greiner, \& Mallikarjunan, 2019). Furthermore, these technologies have demonstrated the capacity to modify proteins' structure and positively impact their functionality (Han, Cai, Cheng, \& Sun, 2018; Queirós, Saraiva, \& da Silva, 2018; Rocha et al., 2018). Particularly, this review will focus on the impact of EF processing in proteins and its potential to control fundamental aspects related to nutrition, functionality and health.

This topic comes on a particularly critical time, where the world population increase and the consumers' perception about sustainability, environmental, health and ethical issues involving production and

Table 1

Examples of emerging protein sources and associated health benefits.

\begin{tabular}{|c|c|c|c|}
\hline Source & Fraction & Biological Activity & References \\
\hline $\begin{array}{l}\text { Pulse (e.g. pea, } \\
\text { chickpea, } \\
\text { lentil, } \\
\text { lupine, mug } \\
\text { bean) }\end{array}$ & $\begin{array}{l}\text { Protein isolates, } \\
\text { protein fraction } \\
\text { and } \\
\text { hydrolysates }\end{array}$ & $\begin{array}{l}\text { Anti-cholesterol } \\
\text { Anti- } \\
\text { hypertriglyceridemic } \\
\text { Heart disease control } \\
\text { Anti-hypertensive } \\
\text { Anti-oxidant } \\
\text { Anti-inflamatory } \\
\text { Anti-carcinogenic } \\
\text { Immunomodulatory } \\
\text { Anti-microbial }\end{array}$ & $\begin{array}{l}\text { (Pihlanto, Mattila, } \\
\text { Mäkinen, \& Pajari, } \\
\text { 2017; Duranti, } \\
\text { Consonni, Magni, } \\
\text { Sessa, \& Scarafoni, } \\
\text { 2008; Arnoldi, } \\
\text { Boschin, Zanoni, \& } \\
\text { Lammi, 2015; Roy, } \\
\text { Boye, \& Simpson, } \\
\text { 2010; Moreno- } \\
\text { Valdespino, Luna- } \\
\text { Vital, Camacho- } \\
\text { Ruiz, \& Mojica, } \\
\text { 2020; Yi-Shen, } \\
\text { Shuai, \& } \\
\text { FitzGerald, 2018) }\end{array}$ \\
\hline $\begin{array}{l}\text { Oilseeds (e.g. } \\
\text { rapeseed } \\
\text { hempseed } \\
\text { soy, } \\
\text { flaxseed) }\end{array}$ & $\begin{array}{l}\text { Protein isolates, } \\
\text { Protein fraction } \\
\text { and } \\
\text { hydrolysates }\end{array}$ & $\begin{array}{l}\text { Anti-cholesterol } \\
\text { Anti- } \\
\text { hypertriglyceridemic } \\
\text { Anti-carcinogenic } \\
\text { Anti-hypertensive } \\
\text { Anti-oxidant } \\
\text { Anti-inflammatory } \\
\text { Against } \\
\text { neurodegenerative } \\
\text { diseases } \\
\text { Immunomodulatory } \\
\text { Anti-inflamatory } \\
\text { Anti-thrombotic } \\
\text { Anti-coagulation } \\
\text { Anti-microbial }\end{array}$ & $\begin{array}{l}\text { (Aider \& Barbana, } \\
\text { 2011; Pihlanto } \\
\text { et al., 2017; Aluko, } \\
\text { 2017; Friedman \& } \\
\text { Brandon, 2001; } \\
\text { Agyei, 2015; } \\
\text { Rabetafika, Van } \\
\text { Remoortel, } \\
\text { Danthine, Paquot, } \\
\text { \& Blecker, 2011) }\end{array}$ \\
\hline $\begin{array}{l}\text { Algae (e.g. } \\
\text { chlorella, } \\
\text { spirulina, } \\
\text { marine } \\
\text { microalgae) }\end{array}$ & $\begin{array}{l}\text { Protein isolates, } \\
\text { Protein fraction } \\
\text { and } \\
\text { hydrolysates }\end{array}$ & $\begin{array}{l}\text { Anti-oxidant } \\
\text { Anti-inflamatory } \\
\text { Anti-hypertensive } \\
\text { Anti-coagulant } \\
\text { Anti-proliferation } \\
\text { Anti-microbial } \\
\text { Anti-tumour } \\
\text { Imunomodulatory }\end{array}$ & $\begin{array}{l}\text { (Samarakoon \& } \\
\text { Jeon, 2012; } \\
\text { Ovando et al., } \\
\text { 2018; Ejike et al., } \\
\text { 2017; Harnedy \& } \\
\text { FitzGerald, 2011; } \\
\text { Hayes et al., 2018) }\end{array}$ \\
\hline $\begin{array}{l}\text { Fungi / } \\
\text { mushroom }\end{array}$ & $\begin{array}{l}\text { Protein isolates } \\
\text { and Protein } \\
\text { fraction }\end{array}$ & $\begin{array}{l}\text { Anti-oxidant } \\
\text { Anti-tumour } \\
\text { Anti-microbial } \\
\text { Anti-hypertensive } \\
\text { Immunomodulatory }\end{array}$ & $\begin{array}{l}\text { (Xu, Yan, Chen, \& } \\
\text { Zhang, 2011; } \\
\text { Zhang et al., 2016; } \\
\text { Hassan, Rouf, } \\
\text { Tiralongo, May, \& } \\
\text { Tiralongo, 2015; } \\
\text { Erjavec, Kos, } \\
\text { Ravnikar, Dreo, \& } \\
\text { Sabotič, 2012) }\end{array}$ \\
\hline Insects & $\begin{array}{l}\text { Flowers, } \\
\text { protein isolates } \\
\text { and } \\
\text { hydrolysates }\end{array}$ & $\begin{array}{l}\text { Anti-microbial } \\
\text { Anti-oxidant } \\
\text { Anti-hypertensiv } \\
\text { Anti-inflamatory } \\
\text { Anti- } \\
\text { hypertriglyceridemic } \\
\text { Anti-tumour }\end{array}$ & $\begin{array}{l}\text { (Neog, Gogoi, } \\
\text { Bordoloi, \& Para, } \\
\text { 2018; Zielińska, } \\
\text { Karaś, Jakubczyk, } \\
\text { Zieliński, \& } \\
\text { Baraniak, 2018; } \\
\text { Chernysh et al., } \\
\text { 2002; Zielińska, } \\
\text { Baraniak, \& Karaś, } \\
\text { 2018; Hall, } \\
\text { Johnson, \& } \\
\text { Liceaga, 2018) }\end{array}$ \\
\hline
\end{tabular}

consumption of conventional proteins sources are pushing the search for sustainable and alternative proteins (Boire et al., 2018; Fasolin et al., 2019). Consequently, new protein sources such as vegetable, microbial and non-conventional animal protein have been studied and used in food science and technology. Despite their recognized potential to replace conventional protein sources, these new proteins usually fall short into delivering the functional and nutritional characteristics required by the industry (Loveday, 2019; Queirós et al., 2018). In order to become an effective alternative, the functionality limitations of these emerging proteins must be overcome. Therefore, along with the exploitation of new protein sources, also the effects of alternative processing strategies (such as the case of EF) must be assessed in two different aspects: i) if beneficial intrinsic characteristics and biological value can be preserved; and ii) if processing can be used to improve functionality, digestibility or reduce allergenicity of some proteins. Along with this new paradigm, the awareness of food-health relationship is increasing and the concept of nutraceuticals and functional foods is turning mainstream (Bagchi \& Nair, 2017). New foods must provide health benefits, assuring prevention, treatment of disease and promoting the general wellbeing. Hence, focus is now being given to the benefits associated with the alternative protein sources. Beyond the content of essential amino acids and their relevance for nutrition and health, the biological value related with the function of certain dietary proteins has been investigated in greater detail (see Table 1). A number of emerging proteins have been reported to present health benefits towards chronic diseases such as high cholesterol levels, hypertension, diabetes, and important biological functions, which include anti-inflammatory or anticarcinogenic activities. Nonetheless, it is necessary to assess the safety and general behavior of these fractions throughout the gastrointestinal tract, including their bioavailability and the evaluation of possible cytotoxic effects or allergic reactions. A fundamental understanding about the interaction between EFs and protein structure may contribute to establish processing protocols with ability to change and control protein functionality aiming at improving their health benefits.

The main objectives of this review are: (i) to address the most promising EF processing technologies; (ii) summarize its recent reported effects on protein molecules; and (iii) provide novel perspectives about EF based processing strategies of protein-rich foods that can bring implications on health and wellbeing.

\section{Electric fields processing}

EF processing is based on the direct use of electric fields to process food, achieving microbial and enzymatic inactivation and/or changes in physicochemical and organoleptic properties. The introduction of EF in the food industry as an alternative to conventional thermal processing occurred in the 1920's when milk pasteurization was performed by the direct use of electricity through a process designated as "electro-pure process", later known as ohmic heating $(\mathrm{OH})$ (Anderson \& Finkelstein, 1919). Over the last years, electro-technologies based on the application of moderate electric fields (MEF) and pulsed electric fields (PEF) have been gaining interest for being efficient, cost-effective and by attaining diverse biological effects (Geada et al., 2018). These technologies can now be found applied with several purposes in numerous fields of research and development, such as food industry (e.g. pasteurization, cooking, blanching), biorefinery (e.g. biomass stabilization, extraction) and medicine (e.g. permeation for drug delivery, tumoral cells elimination). Despites sharing the fundamental working principle (i.e. application of an EF), PEF and MEF rely on different operational specifications and often fulfill distinctive processing objectives (see Table 2).

PEF processing is considered a non-thermal technology that applies high-intensity EF, in the order of $\mathrm{kV} . \mathrm{cm}^{-1}$, through short duration pulses (from ns to $\mathrm{ms}$ ), with the objective of causing electroporation on cellular structures (Geada et al., 2018; Golberg et al., 2016; Rocha et al., 2018). By this reason, PEF has been attracting attention in food industry as a non-thermal pasteurization method, capable of inactivating some 
Table 2

Operational parameters of Electrical Field processing technologies, MEF and PEF.

\begin{tabular}{|c|c|c|c|c|c|c|}
\hline & Electric field strength & Wave/Pulse & Time & $\begin{array}{l}\text { Frequencies } \\
\text { used }\end{array}$ & $\begin{array}{l}\text { Typical maximum } \\
\text { temperatures }\end{array}$ & Main Effects \\
\hline $\begin{array}{l}\text { Moderate Electric } \\
\text { Fields (MEF) }\end{array}$ & $<1000$ V.cm ${ }^{-1}$ & Square or sine & $\begin{array}{l}\text { No upper } \\
\text { limit }\end{array}$ & $0.06-25 \mathrm{kHz}$ & $\begin{array}{l}\text { Sublethal temperatures } \\
\left(<60^{\circ} \mathrm{C}\right) \text { for } \mathrm{MEF} \\
\text { No upper limit for } \mathrm{OH}\end{array}$ & $\begin{array}{l}\text { - Thermal effects associated: } \\
\text { Ohmic Heating (OH) } \\
\text { - Non-thermal inactivation of } \\
\text { some microorganisms } \\
\text { - Extraction of thermolabile } \\
\text { compounds } \\
\text { - Controlling activity of some } \\
\text { enzymes and bacteria } \\
\text { - Change protein structure and } \\
\text { conformation } \\
\text { - Effects of functional } \\
\text { properties of globular } \\
\text { proteins }\end{array}$ \\
\hline $\begin{array}{l}\text { Pulsed Electric } \\
\text { Fields (PEF) }\end{array}$ & $\begin{array}{l}-20 \text { to } 100 \mathrm{kV} \cdot \mathrm{cm}^{-1} \text { (for } \\
\text { microbial inactivation) } \\
-0.5 \text { to } 10 \mathrm{kV} . \mathrm{cm}^{-1} \text { (for } \\
\text { tissue softening) }\end{array}$ & $\begin{array}{l}\text { Square or exponential } \\
\text { decay (unipolar or bipolar) }\end{array}$ & $\begin{array}{l}0.01-2400 \\
\mu \mathrm{s}\end{array}$ & $1-2000 \mathrm{~Hz}$ & $10-60{ }^{\circ} \mathrm{C}$ & $\begin{array}{l}\text { - Electroporation } \\
\text { - Non-thermal inactivation of } \\
\text { microbial cells } \\
\text { - Extraction of thermolabile } \\
\text { compounds } \\
\text { - Change protein structure and } \\
\text { conformation } \\
\text { - Disintegration and softening } \\
\text { cellular tissues }\end{array}$ \\
\hline
\end{tabular}

microorganism at sub-lethal temperatures. The process is defined by the electric pulse characteristics - i.e. shape, duration and frequency - that dictate the total time of the treatment, and the energy input, that is critical to process efficiency and economic impacts of PEF processing. Despites the variety of possibilities, bipolar square pulses demonstrated to be more effective and bring operational advantages such as the reduction of electrode erosion. The pulse intensity, length and number of pulses dictate the extension and specificity of the permeation ability (Gómez et al., 2019; Puértolas \& Barba, 2016).

The inactivation of microorganisms and enzymes associated promoted by PEF with a low thermal load, causes fewer changes in the organoleptic profile and preserves nutritional quality (Blahovec, Vorobiev, \& Lebovka, 2017; Toepfl, Siemer, Saldaña-Navarro, \& Heinz, 2014). However, PEF lethal impact on the cells is always dependent on the electric field strength, treatment time and on the type of the microorganism to be inactivated (Álvarez, Pagán, Condón, \& Raso, 2003; Gómez et al., 2019). Inactivation of more resistant forms of microorganisms through PEF protocols is still a challenge. This normally requires an increase in the number of pulses or the increase of intensity of $\mathrm{EF}$ applied, which in turn increases the chance of heat production through $\mathrm{OH}$ effect during the treatment (Geada et al., 2018; Gómez et al., 2019), thus contradicting the non-thermal nature and declared advantages of the treatment itself. PEF assisted-processing has also been found interesting in operations that involve increased mass extraction of bioactive compounds or molecules from cellular matrices.

$\mathrm{OH}$, also known as Joule heating, is a thermo-electrical processing method which involves heat generated by application of MEF through a food product which acts as an electrical resistance (Knirsch et al., 2010; Yildiz, Bozkurt, \& Icier, 2009). OH is distinguished from electromagnetic heating (e.g. microwave or radiofrequency) by the presence of two electrodes contacting the food (a requirement also need for PEF), assuring a homogeneous heat dispersion through all the sample and a fast heating rate (Pereira \& Vicente, 2010; Sarkis, Mercali, Tessaro, \& Marczak, 2013). OH generally occurs within the range of MEF - i.e. reaching EF intensities from 1 to $1000 \mathrm{~V} . \mathrm{cm}^{-1}$ - usually applying alternating current during an unrestricted time (stretching from a few seconds to several hours) (Rodrigues, Avelar, et al., 2020). The main difference between the $\mathrm{OH}$ and MEF designations lies in the main effects obtained on their application, being $\mathrm{OH}$ related with thermal action while MEF designation is often employed when the primary objective is to exploit EF non-thermal effects, thus minimizing/restricting heat production. In a very simple way, it can be said that $\mathrm{OH}$ will always be one of the main side effects or advantages of MEF application, although it may not always occur. When compared to other conventional heating methods currently in use, $\mathrm{OH}$ appears as an alternative capable of reducing thermal damage due to its direct and volumetric way of heating (Sarkis et al., 2013). Furthermore, the additional effects resulting from the presence of an EF have shown to increase inactivation of certain microorganisms and enzymes, allowing processing at lower temperatures in comparison to a conventional thermal treatment while obtaining equivalent inactivation or pasteurization/sterilization efficiencies (Castro, Macedo, Teixeira, \& Vicente, 2006; Jakób et al., 2010; Machado, Pereira, Martins, Teixeira, \& Vicente, 2010). OH was found advantageous in several thermal unit operations such as thawing, blanching, pasteurization, dehydration and fermentation, but also on biomass bioprocessing and extraction methodologies (Pereira \& Vicente, 2010; Rocha et al., 2018; Rodrigues, Genisheva, et al., 2019).

\section{Electric fields interaction with proteins}

\subsection{Conformation and structure}

The influence of external EF in biological systems and particularly in proteins have attracted the interest of research and numerous authors have tried to disclose their effects using several approaches. Nonetheless, the high responsiveness of proteins to extrinsic factors have been posing difficulties to isolate and study these phenomena at the molecular scale. In recent years, computational techniques such as the use of artificial neural networks or molecular dynamic simulations have contributed greatly to the understanding of protein function and folding at the molecular level (English \& Waldron, 2015; Zhang, Yu, Xia, \& Wang, 2019). These computational techniques allow overcoming limitations of the laboratorial experiments procedures, increasing exponentially the results and analysis, as well as reducing experimental time and costs. Molecular dynamic simulations (MDS) have demonstrated to be particularly useful on the study of the changes of proteins induced by EF (Beebe, 2015; Köhler, Friedrich, \& Fidy, 1998; Xu, Phillips, \& Schulten, 1996). When studying small peptides under EF, structural transitions were observed, such as secondary structural shifts in a $\beta$-amyloid peptide from helical to $\beta$-sheet conformation (Toschi, Lugli, Biscarini, \& Zerbetto, 2009) or a V3-loop shifted to a helix-like conformation (Ojeda-May \& Garcia, 2010). These changes were triggered by a global rearrangement of the dipole moments at the amide planes under $\mathrm{EF}$, which in turn may impair hydrogen bond stability causing 
geometrical arrangement of the structure. Furthermore, it was found that the interactions between the dipole moment and an oscillatory EF determine the orientation of the structure and cause oscillatory motions along the EF alignment (Astrakas, Gousias, \& Tzaphlidou, 2012). These events result in the destabilization of the structure, causing its disruption above a critical EF value; however, even below that value, the $\mathrm{EF}$ oscillation induces mobility restriction which can compromise protein functionality.

MDS involving EF effects in complex and functional proteins, such as myoglobin, revealed a fast transition on their folding, driven by changes on the secondary structure when in presence of a strong EF (Amadei \& Marracino, 2015; Marracino, Apollonio, Liberti, D'Inzeo, \& Amadei, 2013). Several other studies conducted on allergen proteins suggested that EF can change their conformation and activity, thus supposedly changing the immune response that they provoke. The structural modifications described involve shifting hydrogen bonds between the amino acids and structural changes due to changes of the alignment of polar groups towards the direction of the field (Singh et al., 2016; Vanga et al., 2016; Vanga, Singh, \& Raghavan, 2015). Despite their significant contribution to the understanding of effects at molecular scale, MDS present limitations and discrepancies when compared to the obtained results in practical studies about application of EF. These limitations are mostly the consequence of three main reasons: i) the quality of the models available; computational boundaries that limit timescale treatment from nano to microseconds; and iii) due to the fact that the field intensity needed to observe tangible effects within timescales and/or free-energy barriers compatible with the simulation is of several orders of magnitude above that applicable in experimental studies. However, MDS results allow elucidating molecular mechanisms and actually help corroborating some experimental studies. When simulating lysozyme under EF, tangible effects on the proteins secondary structure were reported, being consistent with hydrogen bond breakage and resulting from the alignment of the proteińs dipole moment with the EF (English $\&$ Mooney, 2007). These data agree with experimental results on the influence of PEF in lysozyme (Zhao \& Yang, 2010; Zhao, Yang, Lu, Tang, \& Zhang, 2007). Besides the alignment of the dipole moment with the direction of the EF, the protein unfolding was accompanied by the loss of $\alpha$-helix content, cleavage of disulphide bonds and aggregation. When compared with thermal inactivation of the same protein, PEF caused differentiated structural modifications linked with a structural reorganization, whereas the thermal action caused a more complete unfolding (Zhao \& Yang, 2010). PEF related effects were documented for several proteins and often involve structural and functional changes. Some examples are related with the PEF action in soy protein isolate, resulting in significant changes in the secondary structure, conformation, surface hydrophobicity and free sulfhydryl content, which lead to denaturation and aggregation (Li, 2012; Li, Chen, \& Mo, 2007; Lin, Liang, Li, Xing, \& Yuan, 2016; Xiang, Ngadi, Simpson, Simpson, \& Simpson, 2011). The effects of PEF on other proteins were confirmed by several studies reporting an array of changes such as structural modifications and changes in functional properties which result in an appearance of free sulfhydryl groups, aggregation and decrease of protein solubility (Han et al., 2018; Liu, Oey, Bremer, Carne, \& Silcock, 2017; Wu, Zhao, Yang, $\&$ Chen, 2014). Interestingly the study of PEF treatments on whey protein isolate (WPI) not only revealed conformational disturbances of protein structure, but also that cumulative effects resulting from a conjugation of EF intensity and number of pulses applied are crucial to PEF action (Xiang, Ngadi, Ochoa-Martinez, \& Simpson, 2011).

The cumulative effect seems decisive on the effectiveness of EF in affecting protein structure and functionality. This was verified when determining the effects of the application of low intensity EF (at MEF range) on the conformation of bovine serum albumin and lysozyme (Bekard \& Dunstan, 2014). The application of EF strengths from 0.78 to $5 \mathrm{~V} . \mathrm{cm}^{-1}$, with electrical frequencies of 10 and $500 \mathrm{~Hz}$ (sine wave) and long exposure times (i.e. up to $3 \mathrm{~h}$ ), caused significant effects on proteins' tertiary and secondary structures. It was found that the EF exposure results in frictional forces due to the electrophoretic motion associated with the periodically changing of EF. The resulting energy dissipation is sufficient to disturb hydrogen bonds that stabilize the native fold of the protein, thus resulting in protein unfolding. The low intensity EF effects seem to be particularly dependent of the frequencies used, as demonstrated by studying the effects of frequency associated with MEF on the activity of endogenous enzymes (Samaranayake \& Sastry, 2016, 2018). Operating under a very low EF $\left(<5\right.$ V.cm $\left.{ }^{-1}\right)$ and frequencies between 0 (i.e., DC) and $1 \mathrm{MHz}$, it was established that not only the effects increased with the EF strength, as they were more effective at low electrical frequencies $(<60 \mathrm{~Hz})$. By simulating the molecular motion under an AC field, it was proposed that the frequency dependence arises from the amplitude of motion and resulting displacements due to reversal of the AC field. The effects of MEF in synergy with thermal stress were studied in $\beta$-Lactoglobulin ( $\beta$-Lg), and were found to significantly disturb the protein unfolding pathways. These effects had a linear dependence of the EF strength and despite the observed tangible effects on a large frequency range, $(50 \mathrm{~Hz}$ to $1 \mathrm{MHz})$ they had greater influence at lower frequencies. MEF-induced disturbances resulted in the decrease of the proteins melting temperature and considerable changes in secondary and tertiary structures, as well as in differences in the interaction with ligands (Rodrigues, Avelar, et al., 2020). Other studies with WPI and $\beta$-Lg involving MEF demonstrated that the EF effects are pH-dependent (Rodrigues, Vicente, Petersen, \& Pereira, 2019) and result in changes in free sulfhydryl contents, hydrophobic interactions, hydrogen bonds, aggregation patterns and gelation (Pereira et al., 2016; Rodrigues et al., 2015; Rodrigues, Fasolin, et al., 2020).

There are now compelling evidences of the EF effects in proteins and protein-based foods. Despite the diversity of studies, the fundamental mechanisms involved in these modifications are yet to be fully understood. This lack of knowledge arises from the fact that EF based technologies bring together a great versatility of application protocols. The way how EF is delivered to given matrix can vary greatly depending on parameters such as: intensity of the EF applied; time scale of application; occurrence of ohmic heating and inherent thermal effects; EF and putative occurrence of electrolysis; current density; electrical wave applied (pulsed, non-pulsed, bipolar-pulsed among others). In addition, all these parameters need also to be adjusted to the type of target product or molecule. The way how electricity interacts with molecules will always be dependent on media composition regarding ionic strength, $\mathrm{pH}$ or cosolutes which ultimately changes electrical conductivity of the systems and electric charges distribution of molecules. Many of the highlighted experimental studies report EF effects at macroscale level but now is crucial to gather more knowledge at a more fundamental level in an attempt to identify the mechanisms of interaction of these technologies with important molecules such as proteins, aiming proper control and tailor-made/customized solutions. Based on available state-of-art some of the described EF effects seem to be related with the change of amino acid and peptide interactions, mobility disturbances of specific groups and disruption/reorientation of secondary and tertiary structures. This capacity of changing protein structure is drawing the attention of researchers that wish to harness their potential as a biotechnology tool to change and control protein functionality and protein-protein interactions.

\subsection{Protein interactions}

Protein interactions can be covalent - such as disulphide bonding and non-covalent which include hydrophobic, van der Waals, hydrogen bonds and electrostatic or ionic interactions. These non-covalent interactions are reversible and weak, and mostly dependent of intrinsic and extrinsic factors such as ionic strength, protein concentration, $\mathrm{pH}$ and temperature. Non-covalent interactions when amplified become strong and rule many of the events related with the extent of protein aggregation (Ramos et al., 2014). 
Fundamental knowledge about how to control food protein interactions is of great interest for development of protein networks with high functionality for food but also biomedical applications. Food proteins either from animal or vegetable source are now considered as promising "building blocks" for development of smart biomaterials with ability to interact with bioactive molecules (Fasolin et al., 2019). A controlled denaturation and aggregation of proteins can drastically change biological outcomes (i.e. immunological properties) as well functional properties such as the ones related with emulsifying, gelation and foaming abilities. It is clear that the biological function of a protein depends largely on its three-dimensional structure and conformation, and several encouraging perspectives of research can be highlighted regarding effects of $\mathrm{OH}$ and its $\mathrm{EF}$ in protein functionalization and interaction potential. During the last decade, it has been proven that electrical stimuli can interact with dynamic behavior of globular proteins, affecting their unfolding, denaturation and aggregation pathways, as well as change enzyme activity by affecting their interactions with substrates. As reviewed in previous Section 3.1 evidences are pointing out that EF can promote alterations in a protein's conformational structure thus changing the natural balance of these interactions, which in turn can greatly influence both the functionality and ability to form protein gels and hydrogels from molecular to macroscale (Abaee, Mohammadian, \& Jafari, 2017). But information about the way how these events can be proper controlled is not yet systematized which limits further research at more applied level. For example the influence that these structural outcomes may have on interaction between protein molecules with other macromolecules such as polysaccharides and bioactive compounds (e.g. vitamins, minerals and nutraceuticals) is still undisclosed.

An example of current research concerns the development of protein fibrillar systems. Protein from different sources (such as from whey and soy) can be in vitro designed into 3D supporting architectures, originating biomaterials with discrete morphologies and multifunctionalities - i.e. carrier of bioactive compounds in food formulations, drug delivery systems and network systems for cell communication. One example of these fibrillar systems are the amyloid fibrils, currently defined as a "self-assembled and highly ordered peptide/protein aggregates associated with both disease and function" (Das, Jacob, Patel, Singh, \& Maji, 2018). These systems can be used for the establishment of protein models that can help the design of therapeutic compounds to treat presently incurable protein diseases such as Alzheimer's, Parkinson's and transmissible spongiform encephalopathies, all related with changes in the protein conformation (Wei et al., 2017). These fibrillar systems establish a thin intertwined frontier between food and health encompassing great potential of applications. Mezzenga and co-workers highlight that the final function of these fibrillar systems depends on decisive events: i) the mechanism of protein unfolding and aggregation; ii) the hierarchical structure and size of the produced protein and peptide fibrils (from the atomistic to mesoscopic length scales); (iii) the interaction between proteins and surrounding biological or artificial environments (Cao \& Mezzenga, 2019). Given the body of knowledge already established, it is then obvious that EF may unveil new insights on the development of these systems aiming at tailoring improved functions. One of the major bottlenecks for development of these systems is the need of a controlled aggregation during fibrillation and better understanding about how to favor an organized formation over an amorphous state (Lambrecht et al., 2019). Surface hydrophobicity of globular proteins, such as $\beta-\mathrm{Lg}$, is significantly increased when $\mathrm{EF}$ of moderate intensity is applied under acidic protein solutions (Rodrigues, Vicente, et al., 2019), which is the preferential environment for fibril formation. In addition, internal heating together with EF of moderate intensity can enhance protein hydrolysis, which is often associated with yield of fibril formation (Loveday, Anema, \& Singh, 2017). Pereira and co-workers also concluded that thermal aggregation supported by EF application ranging from 6 to $12 \mathrm{~V} . \mathrm{cm}^{-1}$ resulted in the production of worm-like structures resembling amyloid fibrils (Pereira et al., 2016). In reason of these new evidences, a fundamental understanding of EF effects on interaction between fibril-fibril and fibrilbioactive compounds should be pushed forward in the near future.

Another field of promising research is linked with protein networks and their ability to entrap or establishing molecular interaction with bioactive compounds or other macromolecules. At physiological $\mathrm{pH}$ it has been shown that EF treatment, depending on the frequency and temperature applied, can enhance surface hydrophobicity thus increasing binding affinity or molecular interaction with small hydrophobic compounds. EF show potential to maintain retinol binding within forms of $\beta$-lg exposed to temperatures equal or higher than $70^{\circ} \mathrm{C}$ (Rodrigues, Avelar, et al., 2020). OH have shown also interesting results regarding cold or salt-induced gelation. This gelation strategy consists in unfolding of the protein structure (normally achieved by temperature) followed by shifting the $\mathrm{pH}$ or addition of salts which favor the screening of the electrostatic repulsion between charged molecules. Depending on the processing condition, from conventional control (without the presence of an EF) up to $12 \mathrm{Vcm}^{-1}$, it was possible to incorporate 33 $\mathrm{mmol} \cdot \mathrm{L}^{-1}$ of $\mathrm{Fe}^{2+}$ in the produced protein network, which means that an iron intake of $9 \mathrm{mg}$ /day would be obtained with a daily dose of $5 \mathrm{~mL}$ (teaspoon) of the protein gel (Pereira et al., 2017) In addition, this approach allowed modulating viscosity of the produced system bringing opportunities to develop innovative food thickeners.

Interaction between proteins and polysaccharides through the Maillard reaction (MR), also known by non-enzymatic browning or glycation, is considered a promising way to improve protein technological functional, biological and nutritional properties of food ingredients. MR occurs between amino groups from proteins and the reactive carbonyl group of reducing sugars and is mainly affected by thermal processing (time and temperature) and chemical environment ( $\mathrm{pH}$ and water activity for example). MR has a strong impact on food properties once their reaction products can dictate organoleptic properties but also, antioxidative, antimicrobial, antihypertensive, mutagenic or carcinogenic properties (Jaeger, Janositz, \& Knorr, 2010; Perusko, Al-Hanish, Cirkovic Velickovic, \& Stanic-Vucinic, 2015; Rufián-Henares \& Morales, 2007). MR is rather complex and may alter (positively or negatively) immunological and allergenic outcomes of several proteins, and the resulting advanced glycation end products may trigger differentiated behavior of gut microbiome, thus presenting another example of a thin borderline between a health benefit or disease (Toda, Hellwig, Henle, \& Vieths, 2019). To our best knowledge, the impact of EF on MR is still poorly understood. The behavior of food proteins processed under the influence of direct heating and presence of electrical variables should not be assumed identical to that observed for conventional thermal processing (Pereira et al., 2018). OH brings advantages of reducing heating kinetics and over processing, once it is not conditioned to heat transfer mechanisms relying on conduction and/or convection. Surprisingly, scarce literature can be found about effects of $\mathrm{OH}$ on MR and development of advanced glycated end products, and the existent one is inconclusive and reports the need of more systematic and fundamental assessment (Roux, Courel, Ait-Ameur, Birlouez-Aragon, \& Pain, 2009). In contrast, more studies have been devoted to the beneficial effects of PEF technology on the appearance of 5-hydroxymethylfurfural (HMF), an important intermediate product formed during MR (Jaeger et al., 2010). This outcome is not surprising, given the reduced thermal load associated with PEF processing, and the high temperature dependence for the formation of HMF and thus the occurrence of MR.

\section{Processing of protein-rich food}

\subsection{Quality and safety aspects}

$\mathrm{OH}$ and PEF have been studied over the past few years due to their potential to replace conventional processing techniques. Regarding the maintenance of food quality attributes, these non-conventional technologies are considered superior once they proved to avoid or 
significantly reduce the negative changes in sensorial and nutritional properties of foods associated with processing (Kumar, Agarwal, \& Raghav, 2016; Pereira \& Vicente, 2010).

$\mathrm{OH}$ has been largely applied to dairy and egg products pasteurization in which protein denaturation is one of the major problems because of the occurrence of fouling and product deterioration (Bozkurt \& Icier, 2012; Cappato et al., 2017). OH technology dissipates energy directly within the food material, generating volumetric heating at exceptionally rapid heating rates and it is not dependent on diffusion such as conventional heats exchangers. This results in operational advantages such as reduction of coagulation or excessive denaturation of the constituent proteins (either by faster heating rates and shorter processing time, or by the absence of hot surfaces) resulting in improved nutritional quality and shelf life of food products (Pereira, Martins, \& Vicente, 2008; Pereira \& Vicente, 2010) On the processing of egg products $\mathrm{OH}$ demonstrated to preserve (or even improve) their technological properties, namely colour, rheological behavior, foaming and gelling properties (Alamprese, Cigarini, \& Brutti, 2019). When comparing the effect of $\mathrm{OH}$ and conventional processing on milk pasteurization under the same specific processing conditions, $\mathrm{OH}$ resulted in lower microbial counts, lower D-value and no significant differences in protein denaturation (Sun et al., 2008). For other sensitive foods such as baby food and infant formulae, $\mathrm{OH}$ can also bring processing advantages. A study conducted on vegetable baby purees has shown that $\mathrm{OH}$ allowed to preserve protein quality, when compared to the conventional method (Mesías, Wagner, George, \& Morales, 2016). During ultra-high temperature (UHT) treatment of liquid infant formula by $\mathrm{OH}$ and steam injection, no changes in protein quality were found, however promising results were observed in other chemical markers of $\mathrm{OH}$ treated samples - i.e. vitamin $\mathrm{C}$ preservation and colour retention (Roux et al., 2016).

$\mathrm{OH}$ has been also widely applied in the processing of other proteinrich foods as meat and fish derivatives and soy products. The reported cases on the application of this technology unveiled the potential effect of $\mathrm{OH}$ in inducing macromolecular changes (e.g. microstructure, water retention and texture) on these products. For instance, the use of $\mathrm{OH}$ technology to cook meat balls resulted in brighter colours, lower moisture contents, significantly firmer and even more uniform in microstructure when compared with the conventionally cooked (Engchuan, Jittanit, \& Garnjanagoonchorn, 2014). Tian and co-workers compared the impact of $\mathrm{OH}$ processing and conventional water bath cooking on beef muscle. Due to its fast and homogeneous heating, $\mathrm{OH}$ provides a limited time for the denaturation and aggregation of muscle fibres and connective tissues, thus resulting in a beef product with a significantly lower shear force value, which was reflected in higher tenderness (Tian et al., 2016). Furthermore, in highly processed fish products as surimi, $\mathrm{OH}$ leads to a maximization of the gel functionality due to its associated fast heating rates (Yongsawatdigul, Park, Kolbe, Dagga, \& Morrissey, 1995). When compared to conventional heating methods, OH proved to be a more adequate processing technique for preserving or even improving the microstructural and mechanical attributes of surimi gels (Tadpitchayangkoon, Park, \& Yongsawatdigul, 2012). Research on the $\mathrm{OH}$ processing of soymilk to induce its coagulation for the production of tofu, has revealed a positive impact on the products textural properties (Shimoyamada et al., 2015; Wang et al., 2007). In a more fundamental study, Shimoyamada and co-workers explored the effects of $\mathrm{OH}$ on the structure and functional properties of protein in soybean milk. They verified that the structure and functional properties of protein in soybean milk significantly changed when compared to traditional heating treatment (Shimoyamada et al., 2015).

PEF processing presents a good alternative to conventional pasteurization, since protein-based foods appear to be less affected by this novel processing treatment (once it avoids thermal load), while achieving similar microbial inactivation results (Marco-Molés et al., 2011; Monfort, Saldaña, Condón, Raso, \& Álvarez, 2012). PEF have been successfully applied to pasteurize protein-based foods such as milk and dairy, soymilk and liquid egg. However, the reported studies on this non- conventional technology have been mainly focused in food preservation (i.e. microbial inactivation and associated mechanisms), therefore regarding the impact of PEF in the quality parameters of such treated products further research is still needed (Syed, Ishaq, Rahman, Aslam, \& Shukat, 2017; Zhao, Yang, \& Zhang, 2012). The application of PEF on milk resulted in the modification of its functional properties (Sharma, Oey, \& Everett, 2014, 2016). For instance, PEF-treated milk presented a better rennetability when compared with milk treated by conventional pasteurization. Furthermore, cheddar cheese derived from milk treated by PEF also displayed improved texture and sensory attributes (Sepúlveda-Ahumada, Ortega-Rivas, \& Barbosa-Cánovas, 2000; Yu, Ngadi, \& Raghavan, 2009). Different physical and structural attributes of egg gels, such as microstructure, lipoprotein matrix, water-soluble protein content and mechanical properties seemed to be less affected by PEF treatment when compared to conventional pasteurization (Marco-Molés et al., 2011). In a study conducted by Li and co-workers regarding the quality parameters of soy milk, a successful microbial inactivation was achieved without inducing changes in the products quality characteristics (Y.-Q. Li, Tian, Mo, Zhang, \& Zhao, 2013). Other promising applications of PEF technology is the preservation, aging and tenderization of meat and meat products (Arroyo et al., 2015; Bekhit, van de Ven, Suwandy, Fahri, \& Hopkins, 2014; Faridnia et al., 2015; Gómez et al., 2019).

Independently of the type of protein and media composition many of reported outcomes regarding EF thermal processing are intrinsically linked with the nature of $\mathrm{OH}$ and its ability to generate internal heat thus reducing thermal load and overprocessing, and consequently excessive thermal denaturation of proteins. Once these proteins work as important structural elements, imposed changes at this level have a strong impact in properties such as viscosity, gelation and texture. The direct way of heating and its fast heating kinetics are probably the main reason behind the effects of $\mathrm{OH}$ regarding protein-rich foods, but the presence of electrical variables (i.e. electric field, frequency and current density) and its effects at a molecular level should be systematically assessed in a case-by-case analysis. As mentioned earlier, the presence of EF alone or in combination with heat can promote conformational disorders of the protein, depending on its intensity and manner of application. PEF is a good example supporting this idea, since its mode of action is mostly electric (often considered non-thermal technology), and despite this, significant effects have been reported in the processing of protein-based food products as aformentioned. Due to their unique operational parameters and promising results in preserving and even improving the quality attributes of protein-based products while maintaining their safety to consumers, electrical-based technologies such as $\mathrm{OH}$ and PEF have demonstrated their potential to be used in development of established and innovative food products.

\subsection{Functional systems}

The potential of PEF and OH (including MEF) is now well established to replace conventional thermal processing by improving shelf life (through microbial inactivation) and food quality. However, further research has shown the potential effects of EF application in changing the inherent structure of such food ingredients, giving rise to the formation of novel food ingredients such as gels and films in which their functionality can be tailored for different food applications.

Whey proteins have been comprehensively studied over the last few years, due to their recognized biological value and interesting technological properties (Pereira et al., 2018). The application of OH/MEF on these bio-macromolecules has shown promising results in changing the denaturation and aggregation pathways and possibly allow the design of innovative protein systems such as gels, films and nano/micro structures with tailored functionality (Pereira, Teixeira, \& Vicente, 2011; Rodrigues et al., 2015). It was possible to modify the denaturation levels of WPI solutions in the presence of an electric field, as well as to decrease the percentage of free sulfhydryl groups, reduce the protein aggregates 
size and change their morphology to a fibrillar shape to form gels that can be used in numerous food applications (Pereira et al., 2016). The use of $\mathrm{OH}$ can also be extended to the pre-treatment of globular whey proteins aiming at the development of hydrogels or emulsions that could be used not only as food thickeners, but also as delivery systems of functional biomolecules or bioactives - e.g. heat-sensitive ingredients (Pereira et al., 2018). The application of $\mathrm{OH}$ and MEF on the production of WPI cold-set gels mediated by iron addition contributed to the formation of hydrogels with distinctive properties at micro and macro levels such as a more uniform and compact fine-stranded microstructure (Pereira et al., 2017). The formation of cold gel-like emulsions by using $\mathrm{OH}-$ treated lactoferrin revealed to produce a more flexible structure when compared to conventional heating (de Figueiredo Furtado, Pereira, Vicente, \& Cunha, 2018). The impact of MEF effects on WPI from molecular to macroscopic levels was recently established. The control of MEF variables - i.e. voltage and frequency - during OH treatment of WPI solutions not only affects the protein denaturation and aggregation pathways but also allows controlling the gelation process, inducing molecular interactions, influencing the protein network formation and thus establishing the final gel properties. Moreover, it was also demonstrated that the conjugation of high EF strength and low frequency resulted in the production of weaker gels, with more elastic behaviour and possessing higher water retention and swelling capacity (Rodrigues, Fasolin, et al., 2020). OH treatment also impacts the formation of WPI-based films. Pereira and co-workers reported the attaining of thinner films, with lower permeability to water vapour but similar mechanical properties to the conventional ones. It was suggested that conformational changes on proteins and rearrangements of their secondary structures occurred during the application of $\mathrm{OH}$ could lead to lower protein aggregation and thus the resulting in films with the previously mentioned properties (Pereira, Souza, Cerqueira, Teixeira, \& Vicente, 2010).

Besides the reported studies on whey proteins, $\mathrm{OH}$ has also been applied to other dairy proteins such as casein. The application of $\mathrm{OH}$ on sodium caseinate solutions promoted structural changes (i.e. at secondary and tertiary structures' level) as well the formation of gels with lower values of water holding capacity (Moreira, Pereira, Vicente, \& da Cunha, 2019). The influence of OH pre-treatment of milk prior to promoting the formation of acid milk gels was assessed and compared with conventional heating. In $\mathrm{OH}$ treated samples, the gel firmness was improved due to more compact and denser protein matrices with smaller pore size (Caruggi, Lucisano, Feyissa, Rahimi Yazdi, \& Mohammadifar, 2019). The use of $\mathrm{OH}$ to promote the formation of protein-lipid films by heating soybean milk was also studied. Lei and co-workers have demonstrated the successful production of films with better yield, film formation rate, protein incorporation efficiency and rehydration capacity (Lei, Zhi, Xiujin, Takasuke, \& Zaigui, 2007).

$\mathrm{PEF}$ processing has also shown its potential in modifying the inherent structure of proteins. Despite the growing number of reports on induced changes in proteins, particularly in enzymes (Zhao \& Yang, 2009, 2010; Zhao et al., 2007), the way how this processing technology can be applied to functionalize proteins towards innovative ingredients remains unexplored. In fact, little research has been conducted to explore the modification of molecular structure, or the induced changes in denaturation/aggregation pathways and, thus, in the functional properties of PEF- modified protein-based systems (Giteru, Oey, \& Ali, 2018).

Perez and Pilosof conducted a study to assess the improvement in egg white proteins and $\beta$-Lg gelation after the application of high intensity PEF with long length pulses. The existence of a heating phase seemed to have a synergetic effect with PEF on improving the protein gelation. Moreover, the gelation behavior of both proteins demonstrated to be influenced by PEF treatment. The gelation rate of $\beta-\mathrm{Lg}$ was enhanced, while oppositely egg white proteins suffered a partial decrease in the rate of gelation (Perez \& Pilosof, 2004). Over the last few years, other studies were conducted on the aggregation behavior of egg white proteins caused by PEF treatment, however the exact mechanisms remain unclear and thus require further studies (Wu et al., 2014; Wu, Zhao, Yang, Yan, \& Sun, 2016).

PEF treatment also affects the structure and physicochemical attributes of soy protein isolate (SPI) (Li, 2012; Li et al., 2007). Changes in solubility of SPI were observed after PEF treatment and it was evident that an increase in PEF intensity and processing time was responsible for a decline in solubility, due to protein denaturation and aggregation. Also, some studies evidence the structural modification in whey proteins and their fractions by PEF action. Howeverthe information concerning the mechanisms of action on physicochemical properties is limited and thus the impact on functionalization of such proteins is far from being understood (Sui, Roginski, Williams, Versteeg, \& Wan, 2011; Xiang et al., 2011).

As previously mentioned, there are now strong evidence in the literature regarding the effects of EF on proteins and protein-based foods. However due to the lack of detailed information about their mechanics of action, future research focused on more fundamental studies at molecular scale is needed which may allow establishing EF's potential to fine-tune proteins' functionality.

Global nutritional trends are shifting towards the consumption of novel and sustainable food proteins, already recognized as possessing distinctive nutritional, functional and health attributes. In this context, it would be interesting to gather the information on the electric fieldbased processing of conventional proteins - i.e. dairy, egg and soy proteins - and transfer that knowledge to its application on emergent food proteins, such as vegetable, insect and microbial proteins, aiming at the development of innovative protein-based structures (see Fig. 1).

\subsection{Gastrointestinal digestion}

Information regarding the digestibility and the behavior of food products during gastro intestinal (GI) digestion is fundamental to build a base of knowledge on their interactions and bioavailability within the GI tract. Food proteins are mostly susceptible to hydrolysis from GI enzymes, leading to cleavages in their native structure which allows the release of peptides and amino acids (Hernández-ledesma, Contreras, \& Recio, 2011; Vermeirssen, Camp, \& Verstraete, 2004). In the gastric phase, due to the stomach acidic $\mathrm{pH}$, proteins start to lose their conformation becoming susceptible to hydrolysis, which leads to a release of a small amount of amino acids; further during the intestinal phase a more extended hydrolysis takes place (Hinsberger \& Sandhu, 2004). However, in some cases the GI tract cannot hydrolyze certain resistant proteins. For example, $\beta$-Lg and $\beta$-conglycinin from whey and soy, respectively, are known to be resistant to pepsin during the gastric phase, which may contribute to some allergenicity of these proteins in humans (De Angelis, Pilolli, Bavaro, \& Monaci, 2017; Macierzanka et al., 2012; Moreno, 2007; Nguyen, Bhandari, Cichero, \& Prakash, 2015). These facts highlight the importance of the assessment of GI digestion of proteins, once it will allow determining their bioavailability-related functional aspects such as the release of bioactive peptides and their effects on human health (Orsini Delgado, Tironi, \& Añón, 2011).

Regarding the behavior of proteins during the GI digestion, is also relevant to understand how novel processing treatments, such as EF processing, can change protein digestibility pathways (Bhat, Morton, Mason, \& Bekhit, 2019). The changes in protein digestibility are associated to modifications on their molecular structure; for example, protein unfolding is described to increase proteins' susceptibility to the action of proteases during the GI digestion. Thermal processing is capable of changing $\beta$-Lg's native structure and increase its susceptibility to GI digestion during the gastric phase (Barbé et al., 2013; Pinto et al., 2014). It is also known that protein aggregation during thermal processing can have impact on satiety and digestibility (Promeyrat et al., 2010; Semedo Tavares, Dong, Yang, Zeng, \& Zhao, 2018). Improvements in the digestibility of proteins when treated with PEF have been reported, such as the treatment induced changes on proteins molecular structure, improving digestibly to levels similar to that of conventional cooking (Bhat et al., 2019; Liang, Cheng, \& Wang, 2018; Semedo 


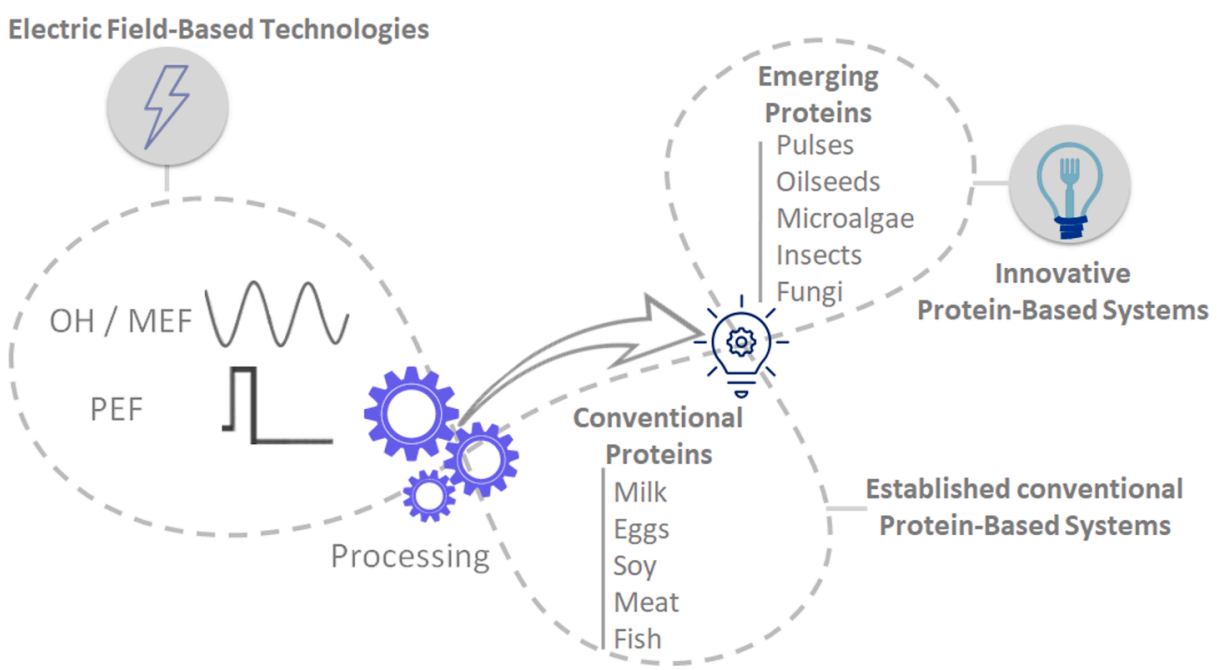

Fig. 1. Future perspectives on the application of EF towards the development of innovative protein-based structures.

Tavares et al., 2018). PEF processing also demonstrated to increase susceptibility to enzymatic hydrolysis of egg white protein (Liu, Oey, Bremer, Silcock, \& Carne, 2018).

The action of high intensity EF also demonstrated to change the secondary structure of peanut and wheat gluten proteins, affecting their digestibility profiles (Vanga et al., 2016). This shows some potential in using EF technologies on food proteins to change their molecular structure, aiming at improving digestibility by exposing specific proteins areas where the GI enzymes can act more efficiently. In fact, any of the structural modifications discussed above, induced by PEF or MEF/OH processing, have the potential to affect the digestibility of the products and affect their nutritional profile. For example, as previously mentioned, $\beta$ - $\mathrm{Lg}$ resists GI digestion due to the high preservation of its hydrophobic regions, as they are the main target to gastric pepsins (Sun, Zhou, Zhao, Yang, \& Cui, 2011). The EF action on this protein is particularly well documented, and recently it was shown that MEF treatments significantly disturb its structure and lead to higher exposure of the hydrophobic pocket (Rodrigues, Avelar, et al., 2020; Rodrigues, Vicente, et al., 2019). This may lead to an increased accessibility of these regions to pepsins and hence higher digestibility, but this need to be further assessed. All the aforementioned EF processing technologies may bring the opportunity to improve the digestibility of some proteins. However, few studies address this topic and more research is needed to fully understand its implications. In addition, the potential negative impacts EF processing on protein function should not be overlooked. The occurrence of irreversible protein aggregates less prone to GI digestion, together with the development of structures or networks with any increased levels of cytotoxicity and immunoreactivity should thoroughly investigated regarding the production of tailored protein-based functional systems for example.

\section{Health implications of EF processing}

\subsection{Allergenicity}

Food allergy is a major problem for the world population, with incidences of around $4 \%$ in adults and $6 \%$ in children (Boye, 2012; Moreno, 2007; Verhoeckx et al., 2015). Food allergy is commonly described as an adverse immune response to certain foods (Sicherer \& Sampson, 2010), and common food products such as milk, soybean, eggs, tree nuts and peanuts, wheat and mustard are considered to trigger immunological responses on humans (Verhoeckx et al., 2015).

Food processing methods can cause biochemical alterations to food components and influence their allergenic properties (Maleki, 2004; Verhoeckx et al., 2015). Particularly proteins may suffer unfolding and aggregation, thus changing their immunoreactivity profile (Bu, Luo, Zheng, \& Zheng, 2009; Mills \& Mackie, 2008). The structure/allergenicity relationship is complex and processing was demonstrated to reduce the allergenicity effects in some cases, but there are exceptions that can display the opposite effect (Fiocchi et al., 1995; Paschke, 2009). Certain allergens are thermostable (such as Ara h 1 from peanuts) and there are some food products which become more allergenic after cooking - e.g. fish and eggs (Maleki, 2004; Paschke, 2009). In the case of globular proteins, such as $\beta-\mathrm{Lg}$ and $\alpha$-lactalbumin, the heating process will unfold them and change the disposition of IgE epitopes, which are responsible by the binding to IgE antibodies (Mills \& Mackie, 2008).

EF processing, as previously discussed, can not only change protein structure and aggregation patterns, but also induce differentiated conformation (compared with e.g. thermal action). This implies that their effect on the allergenic profile of proteins may be distinctive. $\beta-\mathrm{Lg}$ treated by PEF suffered a partial unfolding of the structure contributing to increase the binding to immunoglobulins; however when the PEF treatment was conjugated with glycation of the protein, binding suffered a drastic reduction (Yang, Tu, Wang, Zhang, Kaltashov, et al., 2018). Low intensity PEF treatments of ovalbumin also resulted in the partial unfolding of the protein and the increased binding to antibodies. But when high intensity treatments were applied, the protein became aggregated, causing the reduction of the binding affinity against specific antibodies (Yang, Tu, Wang, Zhang, Gao, et al., 2018).

Pereira and co-workers have recently studied the effects of different pasteurization time/temperature binomials on $\beta$-Lǵs immunoreactivity, by using conventional heating and $\mathrm{OH}$ (Pereira et al., 2020). In their work, the protein's immunoreactivity was correlated with structural data and aggregation patterns. It was suggested that the thermal and electrical variables of $\mathrm{OH}$ changed the balance between monomeric and aggregated forms of the protein, affecting their ability to bind specific antibodies. They also claim that $\mathrm{OH}$ contributed to expose hydrophobic regions of $\beta$ - $\mathrm{Lg}$ (as mentioned before), which are usually protected inside the protein structure, and play an important role on the immune cell activation (Moyano et al., 2012; Pereira et al., 2020).

Some studies have been done regarding different processing methods on the different food allergens and they allow establishing a solid base of knowledge. It is now evident that processing methods can have different effects on the three-dimensional structure of food proteins (see Fig. 2) and consequently their interaction with the human organism, which makes this type of studies of major importance. However, allergenicity issues are rather complex and individual-dependent, which justifies multidisciplinary approaches that should integrate outcomes from GI digestion, different methods of analysis (i.e. in vitro and in vivo) and specialized fields of science. 


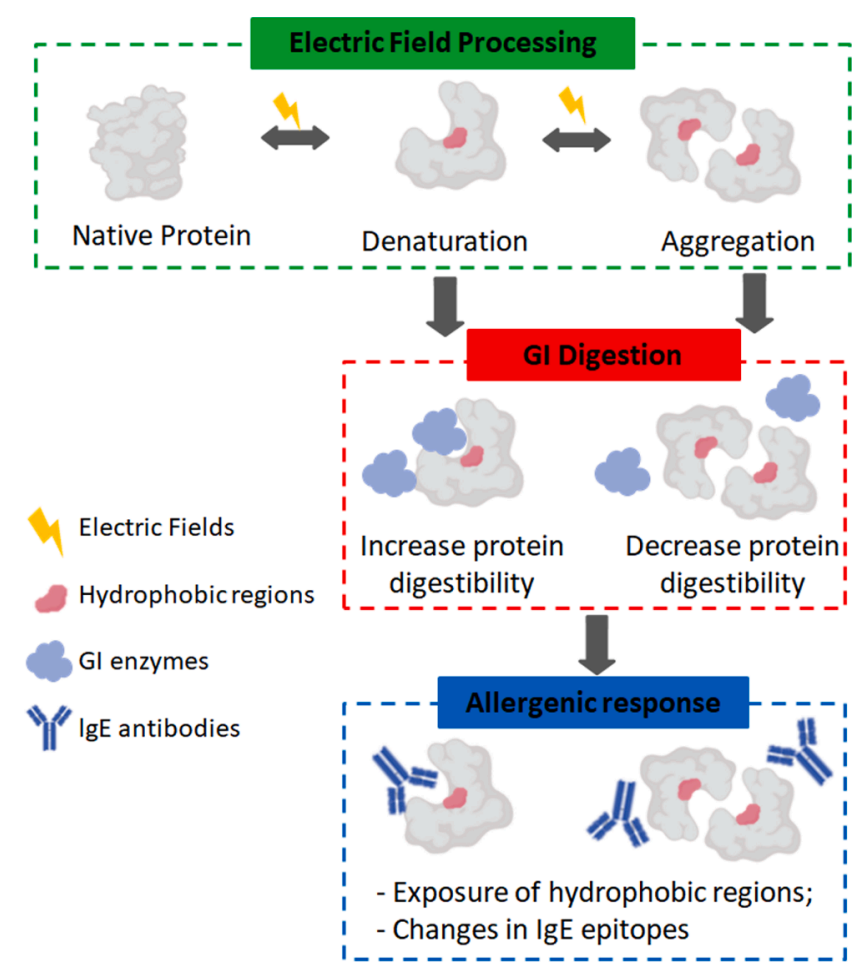

Fig. 2. Schematic representation of the proposed influence of electric fields on protein digestibility and into the lgE-mediated allergenic responses.

\subsection{Bioactivity}

Food proteins and bioactive peptides are described to have a positive impact on human health and body functions (Hernández-ledesma et al., 2011; Korhonen \& Pihlanto, 2006; Orsini Delgado et al., 2011). Among the described properties are antidiabetic, cholesterol-lowering, antihypertensive, anti-cancer, antimicrobial, anti-inflammatory, immunomodulatory, ability to bind vitamins and minerals among others (Daliri, Oh, \& Lee, 2017; Udenigwe \& Aluko, 2012). Among the best described systems are the whey proteins and particularly lactoferrin (Giansanti, Panella, Leboffe, \& Antonini, 2016; McIntosh et al., 1998). Also, some proteins can originate their bioactivity during processing, e.g. through the release of bioactive peptides contained within their polypeptide backbone (Hernández-ledesma et al., 2011; Udenigwe \& Aluko, 2012). The production of these bioactive peptides can be achieved with enzymatic hydrolysis, fermentation, thermal processing, high hydrostatic pressure (HHP) and during food digestion ( $\mathrm{H}$. Korhonen \& Pihlanto, 2003). Several protein sources, such as milk and other dairy products, eggs, soy and some fish species, have been reported as a source of bioactive proteins and peptides (Korhonen \& Pihlanto, 2006; Möller, Scholz-Ahrens, Roos, \& Schrezenmeir, 2008). The structure/function relationship and the ability of EF technologies to preserve quality in foods due to a less aggressive processing, or to intentionally change protein structure and conformation by controlling electric parameters, has already been discussed. This of course is equally applicable to the functional profile of proteins, either by preserving intrinsic characteristics or by promoting structural changes that can alter functionality, cause partial hydrolysis of the protein structure, or modulate digestion profiles (e.g. affecting the release of bioactive peptides).

$\mathrm{PEF}$ processing can have some effects on the bioactive compounds of several food systems (Soliva-Fortuny, Balasa, Knorr, \& Martín-Belloso, 2009). This technique has been applied to improve antioxidant properties of peptides obtained from egg white protein hydrolysis (Lin et al., 2013). The antioxidant properties of peptide fractions suffered an increase of the reducing power from 0.646 to 0.764 after being treated with PEF $\left(10 \mathrm{kV} . \mathrm{cm}^{-1} ; 3000 \mathrm{~Hz}\right)$. The ability of PEF to improve peptides' antioxidant activity was also observed in pine nut peptides, by significantly improving the DPPH radical scavenging (Lin et al., 2017). These results are explained by the ability of PEF processing to induce polarization of peptide molecules and to destroy some bonds and other interactions, changing the peptide basic structure. Other studies with different proteins sources (e.g. corn peptides) have found similar results regarding the effects of PEF on peptides' antioxidant properties (Wang et al., 2015). Besides improvement of the antioxidant properties, PEF have also been described to improve the anti-inflammatory properties of ovomucin-depleted egg white derived peptides (Liu, Oey, Bremer, Carne, \& Silcock, 2019). All these results show preliminary evidences of the advantages of using PEF to improve some functionalities and quality of food products. EF processing methods clearly have the potential to preserve certain products quality, and contribute to the improvement of their nutritional and functional properties. The potentialities of using efficient heating kinetics and high-temperature protocols combined with the electrical effects of high intensity electric fields can enhance protein hydrolysis, thus contributing to the production of bioactive peptides.

\subsection{Future perspectives on the fabrication of biomaterials}

Proteins are the main "building blocks" used for the formation of biomaterials in aqueous environments, as in the case of hydrogels (Choi, Chaudhry, Zo, \& Han, 2018). Hydrogels can retain large amounts of biological fluids within their 3D network, being currently considered as one of the most attractive materials for the development of carriers aiming at controlled release of bioactive compounds or drugs, pharmaceuticals, and production of structured systems for cell communication. Food proteins from underrated sources offer a great potential for the development of these materials, given the easiness of their fabrication process, low cost of raw materials, proven bioactive character, structural flexibility and biocompatibility. Major bottlenecks associated to the use of these proteins are mainly linked with the need of a better understanding about how to control the process of protein aggregation towards envisioning biological and mechanical performances (Choi et al., 2018; Lambrecht et al., 2019). EF may find here an interesting niche of application that needs to be pushed forward. As previously discussed, EF can help to modulated the aggregation process and influence aggregates size, morphology and interactions, requirements needed to design micro or nano drug carriers (Jao, Xue, Medina, \& Hu, 2017). Proteins also have been gaining interest in regenerative medicine and tissue engineering, where they are used for the production of biomaterials such as scaffolds to support cellular growth (Gomes, Leonor, Mano, Reis, \& Kaplan, 2012; O'Brien, 2011; Ribeiro et al., 2016). The proved ability of EF to control protein network formation, from the molecular interactions established to the final network functionality, may present an interesting alternative to modulate and improve the functionality of such networks. On the basis of the aforementioned recent findings, the accurate combination of treatment variables, which include thermal and electrical effects (i.e. electric field, frequency and waveform), can offer an opportunity to tailor protein superstructures with various applications in pharmaceutical and biomedicine fields.

\section{Conclusions}

EF processing is at the frontline of food processing technologies for future use, covering thermal and non-thermal processing, mostly due to their ability to ensure quality and safety to the processed products, while also yielding excellent results in terms of energy efficiency and sustainability regarding the process itself (e.g. use of electrical energy, direct heating process, reduction of the use of water, among others). The possibility of reducing the thermal load is by itself an important benefit for the preservation of the biological value of food proteins. But the ways how thermal and electrical effects physically and chemically affect protein structure and conformation, changing their potential of interaction with other macro and micronutrients, need to be fully addressed. 
These interactions may bring different outcomes regarding the production of protein aggregates with differentiated profile regarding gastrointestinal digestion and immunological responses, while also paving the way to novel applications in other areas of science e.g. those related with health (i.e. biomedicine, regenerative medicine or tissue engineering). The advent of a dietary shift towards alternative proteins from vegetable and microorganism sources bring new challenges about the effects that $\mathrm{EF}$ at an industrial level may have on the biological value, safety issues (i.e. allergenicity and citotoxicity) and important technological properties such as solubility, gelation, emulsifying and flavor, that need to be assessed. To a great extent, all fundamental knowledge about EF effects on proteins has been evaluated using $\beta$ - $\mathrm{Lg}$ as model; this calls for the need to understand how other emergent food proteins would behave under the influence of EF processing protocols. It can be anticipated that commercial technologies such as $\mathrm{OH}$ and PEF will continue to consolidate their industrial position towards minimally processed and shelf-life stable food, but the gathering of fundamental knowledge for development of novel biotechnological applications regarding functionalization/transformation of biomolecules is on its way to expansion, too. Towards this novel positioning, more research efforts should be dedicated to the development of modelling and on-line monitoring tools. Molecular dynamic simulations and artificial neural networks can offer interesting predictions about EF mechanisms of action on proteins. In situ approaches such as the use of spectroscopic methodologies bring an opportunity to understand complex structural dynamics and molecular transitions of proteins in a non-invasive way during processing. These tools can contribute to take intelligent process decision and a comprehensive elucidation of molecular events that often are nonlinear and highly dependent of the surrounding chemical environment and type of protein. Majority of the research studies are still focused on evaluating certain phenomena, rather than a fundamental understanding of how to control them. This results in a wide range of protocols and diversity of approaches that can mask a more general understanding of the electrical effects on macromolecules. From the applied point of view it is also important to note that many potential benefits and singular events occurring under EF influence were prepared/induced to be exponentiated under laboratory conditions, which normally involve complexity reduction, control of external factors and small-scale experiments. Is now important to understand the processing impact of these electric based technologies on real food processing scenarios that bring complex media composition and specific objectives regarding particular unit food operations. A greater involvement of small scale industries in conjunction with the development of research projects that can bring high TRL (level of technological readiness) will be crucial in the future to support the most important results that fundamental research has been providing along these years.

\section{CRediT authorship contribution statement}

Rui M. Rodrigues: Conceptualization, Investigation, Writing original draft, Writing - review \& editing, Project administration. Zita Avelar: Investigation, Writing - original draft. Luís Machado: Investigation, Writing - original draft. Ricardo N. Pereira: Conceptualization, Investigation, Writing - original draft, Writing - review \& editing, Project administration. António A. Vicente: Conceptualization, Writing - review \& editing, Supervision.

\section{Declaration of Competing Interest}

The authors declare that they have no known competing financial interests or personal relationships that could have appeared to influence the work reported in this paper.

\section{Acknowledgements}

This study was supported by the Portuguese Foundation for Science and Technology (FCT) under the scope of the strategic funding of UID/ BIO/04469/2019 and UIDB 50006/2020 with funding from FCT/ MCTES through national funds, BioTecNorte operation (NORTE-010145-FEDER-000004) funded by the European Regional Development Fund under the scope of Norte2020 - Programa Operacional Regional do Norte. This work was also supported by the projects AlleRiskAssess PTDC/BAA-AGR/31720/2017 and NORTE-01-0145-FEDER-031720. Zita Avelar acknowledge the Foundation for Science and Technology (FCT) for its fellowship SFRH/BD/146347/2019.

\section{References}

Abaee, A., Mohammadian, M., \& Jafari, S. M. (2017). Whey and soy protein-based hydrogels and nano-hydrogels as bioactive delivery systems. Trends in Food Science \& Technology, 70, 69-81. https://doi.org/10.1016/j.tifs.2017.10.011

Agyei, D. (2015). Bioactive proteins and peptides from Soybeans. Recent Patents on Food, Nutrition \& Agriculture, 7(2), 100-107. https://doi.org/10.2174/ 2212798407666150629134141

Aider, M., \& Barbana, C. (2011). Canola proteins: Composition, extraction, functional properties, bioactivity, applications as a food ingredient and allergenicity - A practical and critical review. Trends in Food Science \& Technology, 22(1), 21-39. https://doi.org/10.1016/j.tifs.2010.11.002

Alamprese, C., Cigarini, M., \& Brutti, A. (2019). Effects of ohmic heating on technological properties of whole egg. Innovative Food Science \& Emerging Technologies, 58, Article 102244. https://doi.org/10.1016/j.ifset.2019.102244

Aluko, R. E. (2017). Hemp Seed (Cannabis sativa L.) Proteins: Composition, Structure, Enzymatic Modification, and Functional or Bioactive Properties. Sustainable Protein Sources. Elsevier Inc. https://doi.org/10.1016/B978-0-12-802778-3.00007-X.

Álvarez, I., Pagán, R., Condón, S., \& Raso, J. (2003). The influence of process parameters for the inactivation of Listeria monocytogenes by pulsed electric fields. International Journal of Food Microbiology, 87(1-2), 87-95. https://doi.org/10.1016/S0168-1605 (03)00056-4

Amadei, A., \& Marracino, P. (2015). Theoretical-computational modelling of the electric field effects on protein unfolding thermodynamics. RSC Advances, 5(117), 96551-96561. https://doi.org/10.1039/C5RA15605J

Anderson, A. K., \& Finkelstein, R. (1919). A study of the electro-pure process of treating milk. Journal of Dairy Science, 2(5), 374-406. https://doi.org/10.3168/jds.S00220302(19)94338-4

Arnoldi, A., Boschin, G., Zanoni, C., \& Lammi, C. (2015). The health benefits of sweet lupin seed flours and isolated proteins. Journal of Functional Foods, 18, 550-563. https://doi.org/10.1016/j.jff.2015.08.012

Arroyo, C., Eslami, S., Brunton, N. P., Arimi, J. M., Noci, F., \& Lyng, J. G. (2015). An assessment of the impact of pulsed electric fields processing factors on oxidation, color, texture, and sensory attributes of turkey breast meat. Poultry Science, 94(5), 1088-1095. https://doi.org/10.3382/ps/pev097

Aryee, A. N. A., Agyei, D., \& Udenigwe, C. C. (2018). Impact of processing on the chemistry and functionality of food proteins. In Proteins in Food Processing (Second Edi, pp. 27-45). Elsevier. https://doi.org/10.1016/B978-0-08-100722-8.00003-6.

Astrakas, L. G., Gousias, C., \& Tzaphlidou, M. (2012). Structural destabilization of chignolin under the influence of oscillating electric fields. Journal of Applied Physics, 111(7), Article 074702. https://doi.org/10.1063/1.3699389

Bagchi, D., \& Nair, S. (2017). Developing new functional food and nutraceutical products. Elsevier. https://doi.org/10.1016/C2014-0-03724-0

Barbé, F., Ménard, O., Le Gouar, Y., Buffière, C., Famelart, M. H., Laroche, B., Rémond, D. (2013). The heat treatment and the gelation are strong determinants of the kinetics of milk proteins digestion and of the peripheral availability of amino acids. Food Chemistry, 136(3-4), 1203-1212. https://doi.org/10.1016/j. foodchem.2012.09.022

Beebe, S. J. (2015). Considering effects of nanosecond pulsed electric fields on proteins. Bioelectrochemistry, 103, 52-59. https://doi.org/10.1016/j.bioelechem.2014.08.014

Bekard, I., \& Dunstan, D. E. (2014). Electric field induced changes in protein conformation. Soft Matter, 10(3), 431-437. https://doi.org/10.1039/c3sm52653d

Bekhit, A.-E.-D.-A., van de Ven, R., Suwandy, V., Fahri, F., \& Hopkins, D. L. (2014). Effect of pulsed electric field treatment on cold-boned muscles of different potential tenderness. Food and Bioprocess Technology, 7(11), 3136-3146. https://doi.org/ 10.1007/s11947-014-1324-8

Bhat, Z. F., Morton, J. D., Mason, S. L., \& Bekhit, A. E. D. A. (2019). Pulsed electric field improved protein digestion of beef during in-vitro gastrointestinal simulation. Lwt, 102(December 2018), 45-51. https://doi.org/10.1016/j.lwt.2018.12.013.

Blahovec, J., Vorobiev, E., \& Lebovka, N. (2017). Pulsed electric fields pretreatments for the cooking of foods. Food Engineering Reviews, 9(3), 226-236. https://doi.org/ 10.1007/s12393-017-9170-x

Boire, A., Bouchoux, A., Bouhallab, S., Chapeau, A. L., Croguennec, T., Ferraro, V., Anton, M. (2018). Proteins for the future: A soft matter approach to link basic knowledge and innovative applications. Innovative Food Science and Emerging Technologies, 46(June 2017), 18-28. https://doi.org/10.1016/j.ifset.2017.06.012.

Boye, J. I. (2012). Food allergies in developing and emerging economies: Need for comprehensive data on prevalence rates. Clinical and Translational Allergy, 2(25), $1-9$.

Bozkurt, H., \& Icier, F. (2012). The change of apparent viscosity of liquid whole egg during ohmic and conventional heating. Journal of Food Process Engineering, 35(1), 120-133. https://doi.org/10.1111/j.1745-4530.2010.00575.x 
Bryant, C. M., \& McClements, D. J. (1998). Molecular basis of protein functionality with special consideration of cold-set gels derived from heat-denatured whey. Trends in Food Science \& Technology, 9(4), 143-151. https://doi.org/10.1016/S0924-2244(98) 00031-4

Bu, G., Luo, Y., Zheng, Z., \& Zheng, H. (2009). Effect of heat treatment on the antigenicity of bovine $\alpha$-lactalbumin and $\beta$-lactoglobulin in whey protein isolate. Food and Agricultural Immunology, 20(3), 195-206. https://doi.org/10.1080/ 09540100903026116

Cao, Y., \& Mezzenga, R. (2019). Food protein amyloid fibrils: Origin, structure, formation, characterization, applications and health implications. Advances in Colloid and Interface Science, 269, 334-356. https://doi.org/10.1016/j.cis.2019.05.002

Cappato, L. P., Ferreira, M. V. S. S., Guimaraes, J. T., Portela, J. B., Costa, A. L. R. R., Freitas, M. Q., ... Cruz, A. G. (2017). Ohmic heating in dairy processing: Relevant aspects for safety and quality. Trends in Food Science and Technology, 62, 104-112. https://doi.org/10.1016/j.tifs.2017.01.010

Caruggi, N., Lucisano, M., Feyissa, A. H., Rahimi Yazdi, S., \& Mohammadifar, M. A. (2019). Effect of ohmic heating on the formation and texture of acid milk gels. Food Biophysics, 14(3), 249-259. https://doi.org/10.1007/s11483-019-09578-y

Castro, I., Macedo, B., Teixeira, J. A. A., \& Vicente, A. A. A. (2006). The effect of electric field on important food-processing enzymes: Comparison of inactivation kinetics under conventional and ohmic heating. Journal of Food Science, 69(9), C696-C701. https://doi.org/10.1111/j.1365-2621.2004.tb09918.x

Chernysh, S., Kim, S. I., Bekker, G., Pleskach, V. A., Filatova, N. A., Anikin, V. B., Bulet, P. (2002). Antiviral and antitumor peptides from insects. Proceedings of the National Academy of Sciences, 99(20), 12628-12632. https://doi.org/10.1073/ pnas.192301899

Choi, S. M., Chaudhry, P., Zo, S. M., \& Han, S. S. (2018). Advances in protein-based materials: From origin to novel biomaterials. In H. J. Chun, C. H. Park, I. K. Kwon, \& G. Khang (Eds.), Cutting-edge enabling technologies for regenerative medicine (pp. 161-210). Singapore: Springer Singapore. https://doi.org/10.1007/978-981-130950-2_10.

Creighton, T. E. (1993). Proteins: Structures and molecular properties (2nd ed). New York: W.H. Freeman.

Daliri, E.-B.-W., Oh, D. H., \& Lee, B. H. (2017). Bioactive peptides. Foods, 1-21. https:// doi.org/10.3390/foods6050032

Das, S., Jacob, R. S., Patel, K., Singh, N., \& Maji, S. K. (2018). Amyloid Fibrils: Versatile biomaterials for cell adhesion and tissue engineering applications. Biomacromolecules, 19(6), 1826-1839. https://doi.org/10.1021/acs. biomac.8b00279

De Angelis, E., Pilolli, R., Bavaro, S. L., \& Monaci, L. (2017). Insight into the gastroduodenal digestion resistance of soybean proteins and potential implications for residual immunogenicity. Food and Function, 8(4), 1599-1610. https://doi.org/ 10.1039/c6fo01788f

de Figueiredo Furtado, G., Pereira, R. N. C., Vicente, A. A., \& Cunha, R. L. (2018). Cold gel-like emulsions of lactoferrin subjected to ohmic heating. Food Research International, 103, 371-379. https://doi.org/10.1016/j.foodres.2017.10.061

De Vries, H., Mikolajczak, M., Salmon, J. M., Abecassis, J., Chaunier, L., Guessasma, S., ... Trystram, G. (2018). Small-scale food process engineering - Challenges and perspectives. Innovative Food Science and Emerging Technologies, 46(March), 122-130. https://doi.org/10.1016/j.ifset.2017.09.009

Duranti, M., Consonni, A., Magni, C., Sessa, F., \& Scarafoni, A. (2008). The major proteins of lupin seed: Characterisation and molecular properties for use as functional and nutraceutical ingredients. Trends in Food Science \& Technology, 19 (12), 624-633. https://doi.org/10.1016/j.tifs.2008.07.002

Ejike, C. E. C. C., Collins, S. A., Balasuriya, N., Swanson, A. K., Mason, B., \& Udenigwe, C. C. (2017). Prospects of microalgae proteins in producing peptide-based functional foods for promoting cardiovascular health. Trends in Food Science \& Technology, 59, 30-36. https://doi.org/10.1016/j.tifs.2016.10.026

Engchuan, W., Jittanit, W., \& Garnjanagoonchorn, W. (2014). The ohmic heating of meat ball: Modeling and quality determination. Innovative Food Science and Emerging Technologies, 23, 121-130. https://doi.org/10.1016/j.ifset.2014.02.014

English, N. J., \& Mooney, D. A. (2007). Denaturation of hen egg white lysozyme in electromagnetic fields: A molecular dynamics study. The Journal of Chemical Physics, 126(9), Article 091105. https://doi.org/10.1063/1.2515315

English, N. J., \& Waldron, C. J. (2015). Perspectives on external electric fields in molecular simulation: Progress, prospects and challenges. Physical Chemistry Chemical Physics, 17(19), 12407-12440. https://doi.org/10.1039/c5cp00629e

Erjavec, J., Kos, J., Ravnikar, M., Dreo, T., \& Sabotič, J. (2012). Proteins of higher fungi from forest to application. Trends in Biotechnology, 30(5), 259-273. https://doi.org/ 10.1016/j.tibtech.2012.01.004

Faridnia, F., Ma, Q. L., Bremer, P. J., Burritt, D. J., Hamid, N., \& Oey, I. (2015). Effect of freezing as pre-treatment prior to pulsed electric field processing on quality traits of beef muscles. Innovative Food Science \& Emerging Technologies, 29, 31-40. https://doi. org/10.1016/j.ifset.2014.09.007

Fasolin, L. H., Pereira, R. N., Pinheiro, A. C., Martins, J. T., Andrade, C. C. P. P., Ramos, O. L., \& Vicente, A. A. (2019). Emergent food proteins - Towards sustainability, health and innovation. Food Research International. https://doi.org/ 10.1016/j.foodres.2019.108586

Fiocchi, A., Restani, P., Riva, E., Restelli, A. R., Biasucci, G., Galli, C. L., \& Giovannini, M. (1995). Meat allergy: II - Effects of food processing and enzymatic digestion on the allergenicity of bovine and ovine meats. Journal of the American College of Nutrition, 14(3), 245-250. https://doi.org/10.1080/07315724.1995.10718503

Friedman, M., \& Brandon, D. L. (2001). Nutritional and health benefits of soy proteins. Journal of Agricultural and Food Chemistry, 49(3), 1069-1086. https://doi.org/ 10.1021/jf0009246
Geada, P., Rodrigues, R., Loureiro, L., Pereira, R., Fernandes, B., Teixeira, J. A., .. Vicente, A. A. (2018). Electrotechnologies applied to microalgal biotechnology Applications, techniques and future trends. Renewable and Sustainable Energy Reviews, 94, 656-668. https://doi.org/10.1016/j.rser.2018.06.059

Giansanti, F., Panella, G., Leboffe, L., \& Antonini, G. (2016). Lactoferrin from milk: Nutraceutical and pharmacological properties. Pharmaceuticals, 9(4), 1-15. https:// doi.org/10.3390/ph9040061

Giteru, S. G., Oey, I., \& Ali, M. A. (2018). Feasibility of using pulsed electric fields to modify biomacromolecules: A review. Trends in Food Science \& Technology, 72 (December 2017), 91-113. https://doi.org/10.1016/j.tifs.2017.12.009.

Golberg, A., Sack, M., Teissie, J., Pataro, G., Pliquett, U., Saulis, G., ... Frey, W. (2016). Energy-efficient biomass processing with pulsed electric fields for bioeconomy and sustainable development. Biotechnology for Biofuels, 9(1), 1-22. https://doi.org/ 10.1186/s13068-016-0508-Z

Gomes, S., Leonor, I. B., Mano, J. F., Reis, R. L., \& Kaplan, D. L. (2012). Natural and genetically engineered proteins for tissue engineering. Progress in Polymer Science, 37 (1), 1-17. https://doi.org/10.1016/j.progpolymsci.2011.07.003

Gómez, B., Munekata, P. E. S., Gavahian, M., Barba, F. J., Martí-Quijal, F. J., Bolumar, T., ... Lorenzo, J. M. (2019). Application of pulsed electric fields in meat and fish processing industries: An overview. Food Research International, 123(March), 95-105. https://doi.org/10.1016/j.foodres.2019.04.047

Hall, F., Johnson, P. E., \& Liceaga, A. (2018). Effect of enzymatic hydrolysis on bioactive properties and allergenicity of cricket (Gryllodes sigillatus) protein. Food Chemistry, 262, 39-47. https://doi.org/10.1016/j.foodchem.2018.04.058

Han, Z., Cai, M., Cheng, J.-H., \& Sun, D.-W. (2018). Effects of electric fields and electromagnetic wave on food protein structure and functionality: A review. Trends in Food Science \& Technology, 75(November 2017), 1-9. https://doi.org/10.1016/j. tifs.2018.02.017.

Harnedy, P. A., \& FitzGerald, R. J. (2011). Bioactive proteins, peptides, and amino acids from macroalgae. Journal of Phycology, 47(2), 218-232. https://doi.org/10.1111/ j.1529-8817.2011.00969.x

Hassan, M., Rouf, R., Tiralongo, E., May, T., \& Tiralongo, J. (2015). Mushroom lectins: Specificity, structure and bioactivity relevant to human disease. International Journal of Molecular Sciences, 16(12), 7802-7838. https://doi.org/10.3390/ijms16047802

Hayes, M., Bastiaens, L., Gouveia, L., Gkelis, S., Skomedal, H., Skjanes, K., ... Abelho, J. (2018). Microalgal Bioactive Compounds Including Protein, Peptides, and Pigments: Applications, Opportunities, and Challenges During Biorefinery Processes. In Novel Proteins for Food, Pharmaceuticals and Agriculture (pp. 239-255). Chichester, UK: John Wiley \& Sons, Ltd. https://doi.org/10.1002/9781119385332.ch12.

Hernández-ledesma, B., Contreras, M., \& Recio, I. (2011). Antihypertensive peptides : Production, bioavailability and incorporation into foods. Advances in Colloid and Interface Science, 165, 23-35. https://doi.org/10.1016/j.cis.2010.11.001

Hinsberger, A., \& Sandhu, B. K.Ã. (2004). Digestion and absorption. Current Paediatrics, 14, 605-611. https://doi.org/10.1016/j.cupe.2004.08.004

Jaeger, H., Janositz, A., \& Knorr, D. (2010). The Maillard reaction and its control during food processing. The potential of emerging technologies. Vieillissement, 58(3), 207-213. https://doi.org/10.1016/j.patbio.2009.09.016

Jakób, A., Bryjak, J., Wójtowicz, H., Illeová, V., Annus, J., \& Polakovič, M. (2010). Inactivation kinetics of food enzymes during ohmic heating. Food Chemistry, 123(2), 369-376. https://doi.org/10.1016/j.foodchem.2010.04.047

Jao, D., Xue, Y., Medina, J., \& Hu, X. (2017). Protein-based drug-delivery materials. Materials, 10(5), 517. https://doi.org/10.3390/ma10050517

Jia, J., Liu, D., \& Ma, H. (Eds.). (2019). Advances in Food Processing Technology. Advances in Food Processing Technology. Singapore: Springer Singapore. https:// doi.org/10.1007/978-981-13-6451-8.

Knirsch, M. C., dos Santos, C., de Oliveira Soares Vicent, A. A., Vessoni Penna, T. C., Alves dos Santos, C., Martins de Oliveira Soares Vicent, A. A., ... Vessoni Penna, T. C. (2010). Ohmic heating - a review. Trends in Food Science \& Technology, 21(9), 436-441. https://doi.org/10.1016/j.tifs.2010.06.003.

Köhler, M., Friedrich, J., \& Fidy, J. (1998). Proteins in electric fields and pressure fields: Basic aspects. Biochimica et Biophysica Acta - Protein Structure and Molecular Enzymology, 1386(2), 255-288. https://doi.org/10.1016/S0167-4838(98)00098-3

Korhonen, H., \& Pihlanto, A. (2003). Food-derived bioactive peptides - opportunities for designing future foods. Current Pharmaceutical Design, 9(16), 1297-1308. https:// doi.org/10.2174/1381612033454892

Korhonen, H., \& Pihlanto, A. (2006). Bioactive peptides: Production and functionality. International Dairy Journal, 16(9), 945-960. https://doi.org/10.1016/j. idairyj.2005.10.012

Kumar, S., Agarwal, N., \& Raghav, P. (2016). Pulsed electric field processing of foods-A review. International Journal of Engineering Research and Modern Education (IJERME), 1(1), 2455-4200.

Lambrecht, M. A., Jansens, K. J. A., Rombouts, I., Brijs, K., Rousseau, F., Schymkowitz, J., \& Delcour, J. A. (2019). Conditions governing food protein amyloid fibril formation. Part II: Milk and legume proteins. Comprehensive Reviews in Food Science and Food Safety, 18(4), 1277-1291. https://doi.org/10.1111/15414337.12465

Lei, L., Zhi, H., Xiujin, Z., Takasuke, I., \& Zaigui, L. (2007). Effects of different heating methods on the production of protein-lipid film. Journal of Food Engineering, 82(3), 292-297. https://doi.org/10.1016/j.jfoodeng.2007.02.030

Li, Y.-Q. (2012). Structure changes of soybean protein isolates by pulsed electric fields. Physics Procedia, 33, 132-137. https://doi.org/10.1016/j.phpro.2012.05.040

Li, Y.-Q., Tian, W.-L., Mo, H.-Z., Zhang, Y.-L., \& Zhao, X.-Z. (2013). Effects of pulsed electric field processing on quality characteristics and microbial inactivation of soymilk. Food and Bioprocess Technology, 6(8), 1907-1916. https://doi.org/10.1007/ s11947-012-0868-8 
Li, Y., Chen, Z., \& Mo, H. (2007). Effects of pulsed electric fields on physicochemical properties of soybean protein isolates. LWT - Food Science and Technology, 40(7), 1167-1175. https://doi.org/10.1016/j.lwt.2006.08.015

Liang, R., Cheng, S., \& Wang, X. (2018). Secondary structure changes induced by pulsed electric field affect antioxidant activity of pentapeptides from pine nut (Pinus koraiensis) protein. Food Chemistry, 254(1), 170-184. https://doi.org/10.1016/j. foodchem.2018.01.090

Lin, S., Jin, Y., Liu, M., Yang, Y., Zhang, M., Guo, Y., ... Yin, Y. (2013). Research on the preparation of antioxidant peptides derived from egg white with assisting of highintensity pulsed electric field. Food Chemistry, 139(1-4), 300-306. https://doi.org/ 10.1016/j.foodchem.2013.01.048

Lin, S., Liang, R., Li, X., Xing, J., \& Yuan, Y. (2016). Effect of pulsed electric field (PEF) on structures and antioxidant activity of soybean source peptides-SHCMN. Food Chemistry, 213, 588-594. https://doi.org/10.1016/j.foodchem.2016.07.017

Lin, S., Liang, R., Xue, P., Zhang, S., Liu, Z., \& Dong, X. (2017). Antioxidant activity improvement of identified pine nut peptides by pulsed electric field (PEF) and the mechanism exploration. LWT - Food Science and Technology, 75, 366-372. https:// doi.org/10.1016/j.lwt.2016.09.017

Liu, Y.-F. F., Oey, I., Bremer, P., Silcock, P., \& Carne, A. (2018). Proteolytic pattern, protein breakdown and peptide production of ovomucin-depleted egg white processed with heat or pulsed electric fields at different $\mathrm{pH}$. Food Research International, 108(March), 465-474. https://doi.org/10.1016/j.foodres.2018.03.075

Liu, Y.-F., Oey, I., Bremer, P., Carne, A., \& Silcock, P. (2017). Effects of pH, temperature and pulsed electric fields on the turbidity and protein aggregation of ovomucindepleted egg white. Food Research International, 91, 161-170. https://doi.org/ 10.1016/j.foodres.2016.12.005

Liu, Y., Oey, I., Bremer, P., Carne, A., \& Silcock, P. (2019). Modifying the functional properties of egg proteins using novel processing techniques: A review. Comprehensive Reviews in Food Science and Food Safety, 18(4), 986-1002. https://doi. org/10.1111/1541-4337.12464

Loveday, S. M. (2019). Food proteins: Technological, nutritional, and sustainability attributes of traditional and emerging proteins. Annual Review of Food Science and Technology, 10(1), 311-339. https://doi.org/10.1146/annurev-food-032818-121128

Loveday, S. M., Anema, S. G., \& Singh, H. (2017). $\beta$-Lactoglobulin nanofibrils: The long and the short of it. International Dairy Journal, 67, 35-45. https://doi.org/10.1016/j. idairyj.2016.09.011

Machado, L. F., Pereira, R. N., Martins, R. C., Teixeira, J. A., \& Vicente, A. A. (2010). Moderate electric fields can inactivate Escherichia coli at room temperature. Journal of Food Engineering, 96(4), 520-527. https://doi.org/10.1016/j. jfoodeng.2009.08.035

Macierzanka, A., Böttger, F., Lansonneur, L., Groizard, R., Jean, A. S., Rigby, N. M., MacKie, A. R. (2012). The effect of gel structure on the kinetics of simulated gastrointestinal digestion of bovine $\beta$-lactoglobulin. Food Chemistry, 134(4), 2156-2163. https://doi.org/10.1016/j.foodchem.2012.04.018

Maleki, S. J. (2004). Food processing: Effects on allergenicity. Current Opinion in Allergy and Clinical Immunology, 4(3), 241-245. https://doi.org/10.1097/00130832 200406000-00018

Marco-Molés, R., Rojas-Graü, M., Hernando, I., Pérez-Munuera, I., Soliva-Fortuny, R., \& Martin-Belloso, O. (2011). Physical and structural changes in liquid whole egg treated with high-intensity pulsed electric fields. Journal of Food Science, 76, C257-64. https://doi.org/10.1111/j.1750-3841.2010.02016.x

Marracino, P., Apollonio, F., Liberti, M., D’Inzeo, G., \& Amadei, A. (2013). Effect of high exogenous electric pulses on protein conformation: Myoglobin as a case study. The Journal of Physical Chemistry B, 117(8), 2273-2279. https://doi.org/10.1021/ jp309857b

McIntosh, G. H., Royle, P. J., Le Leu, R. K., Regester, G. O., Johnson, M. A., Grinsted, R. L., ... Smithers, G. W. (1998). Whey proteins as functional food ingredients? International Dairy Journal, 8(5-6), 425-434. https://doi.org/10.1016/ S0958-6946(98)00065-X

Mesías, M., Wagner, M., George, S., \& Morales, F. J. (2016). Impact of conventional sterilization and ohmic heating on the amino acid profile in vegetable baby foods. Innovative Food Science \& Emerging Technologies, 34, 24-28. https://doi.org/10.1016 j.ifset.2015.12.031

Mills, E. C., \& Mackie, A. R. (2008). The impact of processing on allergenicity of food. Current Opinion in Allergy and Clinical Immunology, 8(3), 249-253. https://doi.org/ 10.1097/ACI.0b013e3282ffb123

Mirmoghtadaie, L., Shojaee Aliabadi, S., \& Hosseini, S. M. (2016). Recent approaches in physical modification of protein functionality. Food Chemistry, 199, 619-627. https://doi.org/10.1016/j.foodchem.2015.12.067

Möller, N. P., Scholz-Ahrens, K. E., Roos, N., \& Schrezenmeir, J. (2008). Bioactive peptides and proteins from foods: Indication for health effects. European Journal of Nutrition, 47(4), 171-182. https://doi.org/10.1007/s00394-008-0710-2

Monfort, S., Saldaña, G., Condón, S., Raso, J., \& Álvarez, I. (2012). Inactivation of Salmonella spp. in liquid whole egg using pulsed electric fields, heat, and additives. Food Microbiology, 30(2), 393-399. https://doi.org/10.1016/j.fm.2012.01.004

Moreira, T. C. P., Pereira, R. N., Vicente, A. A., \& da Cunha, R. L. (2019). Effect of Ohmic heating on functionality of sodium caseinate - A relationship with protein gelation. Food Research International, 116(April 2018), 628-636. https://doi.org/10.1016/j. foodres.2018.08.087.

Moreno-Valdespino, C. A., Luna-Vital, D., Camacho-Ruiz, R. M., \& Mojica, L. (2020). Bioactive proteins and phytochemicals from legumes: Mechanisms of action preventing obesity and type-2 diabetes. Food Research International, 130(February 2019), 108905. https://doi.org/10.1016/j.foodres.2019.108905.

Moreno, F. J. (2007). Gastrointestinal digestion of food allergens: Effect on their allergenicity. Biomedicine and Pharmacotherapy, 61(1), 50-60. https://doi.org/ 10.1016/j.biopha.2006.10.005
Moyano, D. F., Goldsmith, M., Solfiell, D. J., Landesman-Milo, D., Miranda, O. R., Peer, D., \& Rotello, V. M. (2012). Nanoparticle hydrophobicity dictates immune response. Journal of the American Chemical Society, 134(9), 3965-3967. https://doi. org/10.1021/ja2108905

Neog, P., Gogoi, M., Bordoloi, P. L., \& Para, P. A. (2018). Edible Insects as Sources of Novel Bioactive Compounds. In Recent Research Trends in Veterinary Sciences and Animal Husbandry (pp. 55-69). AkiNik Publications.

Nguyen, T. T. P., Bhandari, B., Cichero, J., \& Prakash, S. (2015). Gastrointestinal digestion of dairy and soy proteins in infant formulas: An in vitro study. Food Research International, 76, 348-358. https://doi.org/10.1016/j.foodres.2015.07.030

O'Brien, F. J. (2011). Biomaterials \& scaffolds for tissue engineering. Materials Today, 14 (3), 88-95. https://doi.org/10.1016/S1369-7021(11)70058-X

Ojeda-May, P., \& Garcia, M. E. (2010). Electric field-driven disruption of a native $\beta$-sheet protein conformation and generation of a Helix-structure. Biophysical Journal, 99(2), 595-599. https://doi.org/10.1016/j.bpj.2010.04.040

Onuchic, J. N., Luthey-Schulten, Z., \& Wolynes, P. G. (1997). Theory of protein folding: The energy landscape perspective. Annual Review of Physical Chemistry, 48(1), 545-600. https://doi.org/10.1146/annurev.physchem.48.1.545

Orsini Delgado, M. C., Tironi, V. A., \& Añón, M. C. (2011). Antioxidant activity of amaranth protein or their hydrolysates under simulated gastrointestinal digestion. LWT - Food Science and Technology, 44(8), 1752-1760. https://doi.org/10.1016/j. lwt.2011.04.002

Ovando, C. A., de Carvalho, J. C., de Melo, Vinícius, Pereira, G., Jacques, P., Soccol, V. T., \& Soccol, C. R. (2018). Functional properties and health benefits of bioactive peptides derived from Spirulina: A review. Food Reviews International, 34(1), 34-51. https://doi.org/10.1080/87559129.2016.1210632

Paschke, A. (2009). Aspects of food processing and its effect on allergen structure Molecular Nutrition and Food Research, 53(8), 959-962. https://doi.org/10.1002/ mnfr. 200800187

Pereira, R. N., Costa, J., Rodrigues, R. M., Villa, C., Machado, L., Mafra, I., \& Vicente, A. (2020). Effects of ohmic heating on the immunoreactivity of $\beta$-lactoglobulin - a relationship towards structural aspects. Food \& Function. https://doi.org/10.1039/ c9fo02834j

Pereira, R. N., Martins, R. C., \& Vicente, A. A. (2008). Goat milk free fatty acid characterization during conventional and ohmic heating pasteurization. Journal of Dairy Science, 91(8), 2925-2937. https://doi.org/10.3168/jds.2007-0873

Pereira, R. N., Rodrigues, R. M., Altinok, E., Ramos, Ó. L., Xavier Malcata, F., Maresca, P., ... Vicente, A. A. (2017). Development of iron-rich whey protein hydrogels following application of ohmic heating - Effects of moderate electric fields. Food Research International, 99, 435-443. https://doi.org/10.1016/j.foodres.2017.05.023

Pereira, R. N., Rodrigues, R. M., Ramos, Ó. L., Xavier Malcata, F., Teixeira, J. A., \& Vicente, A. A. (2016). Production of whey protein-based aggregates under ohmic heating. Food and Bioprocess Technology, 9(4), 576-587. https://doi.org/10.1007/ s11947-015-1651-4

Pereira, R. N., Souza, B. W. S., Cerqueira, M. A., Teixeira, J. A., \& Vicente, A. A. A. (2010). Effects of electric fields on protein unfolding and aggregation: Influence on edible films formation. Biomacromolecules, 11(11), 2912-2918. https://doi.org/ 10.1021/bm100681a

Pereira, R. N., Teixeira, J. A., \& Vicente, A. A. (2011). Exploring the denaturation of whey proteins upon application of moderate electric fields: A kinetic and thermodynamic study. Journal of Agricultural and Food Chemistry, 59(21), 11589-11597. https://doi.org/10.1021/jf201727s

Pereira, R. N., \& Vicente, A. A. (2010). Environmental impact of novel thermal and nonthermal technologies in food processing. Food Research International, 43(7), 1936-1943. https://doi.org/10.1016/j.foodres.2009.09.013

Pereira, R., Teixeira, J. A., Vicente, A. A., Cappato, L. P., da Silva Ferreira, M. V., da Silva Rocha, R., \& da Cruz, A. G. (2018). Ohmic heating for the dairy industry: A potential technology to develop probiotic dairy foods in association with modifications of whey protein structure. Current Opinion in Food Science, 22, 95-101. https://doi.org/ 10.1016/j.cofs.2018.01.014

Perez, O. E., \& Pilosof, A. M. R. R. (2004). Pulsed electric fields effects on the molecular structure and gelation of $\beta$-lactoglobulin concentrate and egg white. Food Research International, 37(1), 102-110. https://doi.org/10.1016/j.foodres.2003.09.008

Perusko, M., Al-Hanish, A., Cirkovic Velickovic, T., \& Stanic-Vucinic, D. (2015). Macromolecular crowding conditions enhance glycation and oxidation of whey proteins in ultrasound-induced Maillard reaction. Food Chemistry, 177, 248-257. https://doi.org/10.1016/j.foodchem.2015.01.042

Pihlanto, A., Mattila, P., Mäkinen, S., \& Pajari, A. M. (2017). Bioactivities of alternative protein sources and their potential health benefits. Food and Function, 8(10), 3443-3458. https://doi.org/10.1039/c7fo00302a

Pinto, M. S., Léonil, J., Henry, G., Cauty, C., Carvalho, A.Ô. F., \& Bouhallab, S. (2014). Heating and glycation of $\beta$-lactoglobulin and $\beta$-casein: Aggregation and in vitro digestion. Food Research International, 55, 70-76. https://doi.org/10.1016/j. foodres.2013.10.030

Priyadarshini, A., Rajauria, G., O’Donnell, C. P., \& Tiwari, B. K. (2018). Emerging food processing technologies and factors impacting their industrial adoption. Critical Reviews in Food Science and Nutrition, 1-20. https://doi.org/10.1080/ 10408398.2018.1483890

Promeyrat, A., Gatellier, P., Lebret, B., Kajak-siemaszko, K., Aubry, L., \& Santélhoutellier, V. (2010). Evaluation of protein aggregation in cooked meat. Food Chemistry, 121(2), 412-417. https://doi.org/10.1016/j.foodchem.2009.12.057

Puértolas, E., \& Barba, F. J. (2016). Electrotechnologies applied to valorization of byproducts from food industry: Main findings, energy and economic cost of their industrialization. Food and Bioproducts Processing, 100, 172-184. https://doi.org/ 10.1016/j.fbp.2016.06.020 
Queirós, R. P., Saraiva, J. A., \& da Silva, J. A. L. L. (2018). Tailoring structure and technological properties of plant proteins using high hydrostatic pressure. Critical Reviews in Food Science and Nutrition, 58(9), 1538-1556. https://doi.org/10.1080/ 10408398.2016.1271770

Rabetafika, H. N., Van Remoortel, V., Danthine, S., Paquot, M., \& Blecker, C. (2011). Flaxseed proteins: Food uses and health benefits. International Journal of Food Science and Technology, 46(2), 221-228. https://doi.org/10.1111/j.1365-2621.2010.02477. $\mathrm{x}$

Ramos, O. L. O. L., Pereira, R. N. R. N., Rodrigues, R., Teixeira, J. A. J. A., Vicente, A. A. A. A., \& Xavier Malcata, F. (2014). Physical effects upon whey protein aggregation for nano-coating production. Food Research International, 66, 344-355. https://doi.org/10.1016/j.foodres.2014.09.036

Ribeiro, A., Volkov, V., Oliveira, M. B., Padrão, J., Mano, J. F., Gomes, A. C., \& CavacoPaulo, A. (2016). BSA/HSA ratio modulates the properties of $\mathrm{Ca} 2+$-induced cold gelation scaffolds. International Journal of Biological Macromolecules, 89, 535-544. https://doi.org/10.1016/j.ijbiomac.2016.05.012

Rocha, C. M. R., Genisheva, Z., Ferreira-Santos, P., Rodrigues, R., Vicente, A. A., Teixeira, J. A., \& Pereira, R. N. (2018). Electric field-based technologies for valorization of bioresources. Bioresource Technology, 254. https://doi.org/10.1016/j. biortech.2018.01.068

Rodrigues, R. M., Avelar, Z., Vicente, A. A., Petersen, S. B., Pereira, R. N., Petersen, B., \& Pereira, R. N. (2020). Influence of moderate electric fields in $\beta$-lactoglobulin therma unfolding and interactions. Food Chemistry, 304(March 2019). https://doi.org/ 10.1016/j.foodchem.2019.125442.

Rodrigues, R. M., Fasolin, L. H., Avelar, Z., Petersen, S. B., Vicente, A. A., Pereira, R. N., ... Tian, Y. (2020). Effects of moderate electric fields on cold-set gelation of whey proteins - From molecular interactions to functional properties. Food Hydrocolloids, 101(November 2019). https://doi.org/10.1016/j.foodhyd.2019.105505.

Rodrigues, R. M., Genisheva, Z., Rocha, C. M. R., Teixeira, J. A., Vicente, A. A., \& Pereira, R. N. (2019). Ohmic heating for preservation, transformation, and extraction. In F. Chemat, \& E. B. T.-. G. F. P. T. Vorobiev (Eds.), Green Food Processing Techniques- Preservation, Transformation and Extraction, 6 pp. 159-191). Academic Press.

Rodrigues, R. M., Martins, A. J., Ramos, O. L., Malcata, F. X., Teixeira, J. A., Vicente, A. A., \& Pereira, R. N. (2015). Influence of moderate electric fields on gelation of whey protein isolate. Food Hydrocolloids, 43, 329-339. https://doi.org/ 10.1016/j.foodhyd.2014.06.002

Rodrigues, R. M., Vicente, A. A., Petersen, S. B., \& Pereira, R. N. (2019). Electric field effects on $\beta$-lactoglobulin thermal unfolding as a function of $\mathrm{pH}$ - Impact on protein functionality. Innovative Food Science \& Emerging Technologies, 52(November 2018), 1-7. https://doi.org/10.1016/j.ifset.2018.11.010.

Roohinejad, S., Koubaa, M., Greiner, R., \& Mallikarjunan, K. (2019). Effect of Emerging Processing Methods on the Food Quality. In S. Roohinejad, M. Koubaa, R. Greiner, \& K. Mallikarjunan (Eds.), Effect of Emerging Processing Methods on the Food Quality. Cham: Springer International Publishing. https://doi.org/10.1007/978-3-03018191-8.

Roux, S., Courel, M., Ait-Ameur, L., Birlouez-Aragon, I., \& Pain, J.-P. (2009). Kinetics of Maillard reactions in model infant formula during UHT treatment using a static batch ohmic heater. Dairy Science \& Technology, 89(3), 349-362. https://doi.org/ $10.1051 /$ dst $/ 2009015$

Roux, S., Courel, M., Birlouez-Aragon, I., Municino, F., Massa, M., \& Pain, J.-P. (2016). Comparative thermal impact of two UHT technologies, continuous ohmic heating and direct steam injection, on the nutritional properties of liquid infant formula. Journal of Food Engineering, 179, 36-43. https://doi.org/10.1016/j. jfoodeng.2016.02.001

Roy, F., Boye, J. I., \& Simpson, B. K. (2010). Bioactive proteins and peptides in pulse crops : Pea, chickpea and lentil. Food Research International, 43(2), 432-442. https:// doi.org/10.1016/j.foodres.2009.09.002

Rufián-Henares, J. A., \& Morales, F. J. (2007). Functional properties of melanoidins: In vitro antioxidant, antimicrobial and antihypertensive activities. Food Research International, 40(8), 995-1002. https://doi.org/10.1016/j.foodres.2007.05.002

Samarakoon, K., \& Jeon, Y.-J. (2012). Bio-functionalities of proteins derived from marine algae - A review. Food Research International, 48(2), 948-960. https://doi.org/ 10.1016/j.foodres.2012.03.013

Samaranayake, C. P., \& Sastry, S. K. (2016). Effects of controlled-frequency moderate electric fields on pectin methylesterase and polygalacturonase activities in tomato homogenate. Food Chemistry, 199(Supplement C), 265-272.

Samaranayake, C. P., \& Sastry, S. K. (2018). LWT - Food Science and Technology In-situ activity of $\alpha$-amylase in the presence of controlled-frequency moderate electric fi elds. LWT - Food Science and Technology, 90(October 2017), 448-454. https://doi. org/10.1016/j.lwt.2017.12.053.

Sarkis, J. R., Mercali, G. D., Tessaro, I. C., \& Marczak, L. D. F. (2013). Evaluation of key parameters during construction and operation of an ohmic heating apparatus. Innovative Food Science and Emerging Technologies, 18, 145-154. https://doi.org/ 10.1016/j.ifset.2013.02.001

Semedo Tavares, W. P., Dong, S., Yang, Y., Zeng, M., \& Zhao, Y. (2018). Influence of cooking methods on protein modification and in vitro digestibility of hairtail (Thichiurus lepturus) fillets. LWT - Food Science and Technology, 96(June), 476-481. https://doi.org/10.1016/j.lwt.2018.06.006

Sepúlveda-Ahumada, D. R., Ortega-Rivas, E., \& Barbosa-Cánovas, G. V. (2000). Quality aspects of cheddar cheese obtained with milk pasteurized by pulsed electric fields. Food and Bioproducts Processing, 78(2), 65-71. https://doi.org/10.1205/ 096030800532752

Sharma, P., Oey, I., \& Everett, D. W. (2014). Effect of pulsed electric field processing on the functional properties of bovine milk. Trends in Food Science \& Technology, 35(2), 87-101. https://doi.org/10.1016/j.tifs.2013.11.004
Sharma, P., Oey, I., \& Everett, D. W. (2016). Thermal properties of milk fat, xanthine oxidase, caseins and whey proteins in pulsed electric field-treated bovine whole milk. Food Chemistry, 207, 34-42. https://doi.org/10.1016/j.foodchem.2016.03.076 Shimoyamada, M., Itabashi, Y., Sugimoto, I., Kanauchi, M., Ishida, M., Tsuzuki, K., Honda, Y. (2015). Characterization of Soymilk Prepared by Ohmic Heating and the Effects of Voltage Applied. Food Science and Technology Research, 21(3), 439-444. https://doi.org/10.3136/fstr.21.439

Sicherer, S. H., \& Sampson, H. A. (2010). Food allergy. Journal of Allergy and Clinical Immunology, 125(2), S116-S125. https://doi.org/10.1016/j.jaci.2009.08.028

Singh, A., Lahlali, R., Vanga, S. K., Karunakaran, C., Orsat, V., \& Raghavan, V. (2016). Effect of High Electric Field on Secondary Structure of Wheat Gluten. International Journal of Food Properties, 19(6), 1217-1226. https://doi.org/10.1080/ 10942912.2015.1076458

Soliva-Fortuny, R., Balasa, A., Knorr, D., \& Martín-Belloso, O. (2009). Effects of pulsed electric fields on bioactive compounds in foods: A review. Trends in Food Science \& Technology, 20(11-12), 544-556. https://doi.org/10.1016/j.tifs.2009.07.003

Sui, Q., Roginski, H., Williams, R. P. W., Versteeg, C., \& Wan, J. (2011). Effect of pulsed electric field and thermal treatment on the physicochemical and functional properties of whey protein isolate. International Dairy Journal, 21(4), 206-213. https://doi.org/10.1016/j.idairyj.2010.11.001

Sun, H., Kawamura, S., Himoto, J., Itoh, K., Wada, T., \& Kimura, T. (2008). Effects of ohmic heating on microbial counts and denaturation of proteins in milk. Food Science and Technology Research, 14(2), 117-123. https://doi.org/10.3136/ fstr.14.117.

Sun, W., Zhou, F., Zhao, M., Yang, B., \& Cui, C. (2011). Physicochemical changes of myofibrillar proteins during processing of Cantonese sausage in relation to their aggregation behaviour and in vitro digestibility. Food Chemistry, 129(2), 472-478. https://doi.org/10.1016/j.foodchem.2011.04.101

Syed, Q. A., Ishaq, A., Rahman, U., Aslam, S., \& Shukat, R. (2017). Pulsed electric field technology in food preservation: A review. Journal of Nutritional Health \& Food Engineering, 6(6), 168-172. https://doi.org/10.15406/jnhfe.2017.06.00219

Tadpitchayangkoon, P., Park, J. W., \& Yongsawatdigul, J. (2012). Gelation characteristics of tropical surimi under water bath and ohmic heating. LWT - Food Science and Technology, 46(1), 97-103. https://doi.org/10.1016/j.lwt.2011.10.020

Tian, X., Wu, W., Yu, Q., Hou, M., Jia, F., Li, X., \& Dai, R. (2016). Quality and proteome changes of beef M.longissimus dorsi cooked using a water bath and ohmic heating process. Innovative Food Science and Emerging Technologies, 34, 259-266. https://doi. org/10.1016/j.ifset.2016.02.013

Toda, M., Hellwig, M., Henle, T., \& Vieths, S. (2019). Influence of the maillard reaction on the allergenicity of food proteins and the development of allergic inflammation. Current Allergy and Asthma Reports, 19(1), 4. https://doi.org/10.1007/s11882-0190834-X

Toepfl, S., Siemer, C., Saldaña-Navarro, G., \& Heinz, V. (2014). Overview of Pulsed Electric Fields Processing for Food. In Emerging Technologies for Food Processing (pp. 93-114). Elsevier. https://doi.org/10.1016/B978-0-12-411479-1.00006-1.

Toschi, F., Lugli, F., Biscarini, F., \& Zerbetto, F. (2009). Effects of electric field stress on a $\beta$-amyloid peptide. The Journal of Physical Chemistry B, 113(1), 369-376. https://doi. org/10.1021/jp807896g

Udenigwe, C. C., \& Aluko, R. E. (2012). Food protein-derived bioactive peptides: Production, processing, and potential health benefits. Journal of Food Science, 77(1), 11-24. https://doi.org/10.1111/j.1750-3841.2011.02455.x

Vanga, S. K., Singh, A., Kalkan, F., Gariepy, Y., Orsat, V., \& Raghavan, V. (2016). Effect of thermal and high electric fields on secondary structure of peanut protein. International Journal of Food Properties, 19(6), 1259-1271. https://doi.org/10.1080/ 10942912.2015.1071841

Vanga, S. K., Singh, A., \& Raghavan, V. (2015). Effect of thermal and electric field treatment on the conformation of Ara h 6 peanut protein allergen. Innovative Food Science \& Emerging Technologies, 30, 79-88. https://doi.org/10.1016/j. ifset.2015.03.003

Vanga, S. K., Singh, A., \& Raghavan, V. (2017). Review of conventional and novel food processing methods on food allergens. Critical Reviews in Food Science and Nutrition, 57(10), 2077-2094. https://doi.org/10.1080/10408398.2015.1045965

Verhoeckx, K. C. M., Vissers, Y. M., Baumert, J. L., Faludi, R., Feys, M., Flanagan, S., .. Bayer, S. A. S. (2015). Food processing and allergenicity. Food and Chemical Toxicology, 80, 223-240. https://doi.org/10.1016/j.fct.2015.03.005

Vermeirssen, V., Camp, J. Van, \& Verstraete, W. (2004). Bioavailability of angiotensin I converting enzyme inhibitory peptides. British Journal of Nutrition, 92, 357-366. https://doi.org/10.1079/BJN20041189

Wang, K., Wang, Y., Lin, S., Liu, X., Yang, S., \& Jones, G. S. (2015). Analysis of DPPH inhibition and structure change of corn peptides treated by pulsed electric field technology. Journal of Food Science and Technology, 52(7), 4342-4350. https://doi. org/10.1007/s13197-014-1450-3

Wang, L.-J., Li, D., Tatsumi, E., Liu, Z.-S., Chen, X. D., \& Li, L.-T. (2007). Application of two-stage ohmic heating to tofu processing. Chemical Engineering and Processing: Process Intensification, 46(5), 486-490. https://doi.org/10.1016/j.cep.2006.06.017

Wei, G., Su, Z., Reynolds, N. P., Arosio, P., Hamley, I. W., Gazit, E., \& Mezzenga, R. (2017). Self-assembling peptide and protein amyloids: From structure to tailored function in nanotechnology. Chemical Society Reviews, 46(15), 4661-4708. https:// doi.org/10.1039/C6CS00542J

Wu, L., Zhao, W., Yang, R., \& Chen, X. (2014). Effects of pulsed electric fields processing on stability of egg white proteins. Journal of Food Engineering, 139, 13-18. https:// doi.org/10.1016/j.jfoodeng.2014.04.008

Wu, L., Zhao, W., Yang, R., Yan, W., \& Sun, Q. (2016). Aggregation of egg white proteins with pulsed electric fields and thermal processes. Journal of the Science of Food and Agriculture, 96(10), 3334-3341. https://doi.org/10.1002/jsfa.7512 
Xiang, B. Y., Ngadi, M. O., Ochoa-Martinez, L. A., \& Simpson, M. V. (2011). Pulsed Electric Field-Induced Structural Modification of Whey Protein Isolate. Food and Bioprocess Technology, 4(8), 1341-1348. https://doi.org/10.1007/s11947-009-0266Z

Xiang, B. Y., Ngadi, M. O., Simpson, B. K., Simpson, M. V., \& Simpson, V. M. (2011). Pulsed electric field induced structural modification of soy protein isolate as studied by fluorescence spectroscopy. Journal of Food Processing and Preservation, 35(5), 563-570. https://doi.org/10.1111/j.1745-4549.2010.00501.x

Xu, D., Phillips, J. C., \& Schulten, K. (1996). Protein response to external electric fields: Relaxation, hysteresis, and echo. Journal of Physical Chemistry, 100(29), 12108-12121. https://doi.org/10.1021/jp960076a

Xu, X., Yan, H., Chen, J., \& Zhang, X. (2011). Bioactive proteins from mushrooms. Biotechnology Advances, 29(6), 667-674. https://doi.org/10.1016/j. biotechadv.2011.05.003

Yang, W., Tu, Z., Wang, H., Zhang, L., Gao, Y., Li, X., \& Tian, M. (2018). Immunogenic and structural properties of ovalbumin treated by pulsed electric fields. International Journal of Food Properties, 20(3), S3164-S3176. https://doi.org/10.1080/ 10942912.2017.1396479

Yang, W., Tu, Z., Wang, H., Zhang, L., Kaltashov, I. A., Zhao, Y., ... Ye, W. (2018). The mechanism of reduced IgG/IgE-binding of $\beta$-lactoglobulin by pulsed electric field pretreatment combined with glycation revealed by ECD/FTICR-MS. Food and Function, 9(1), 417-425. https://doi.org/10.1039/c7fo01082f

Yi-Shen, Z., Shuai, S., \& FitzGerald, R. (2018). Mung bean proteins and peptides: Nutritional, functional and bioactive properties. Food \& Nutrition Research, 62.

Yildiz, H., Bozkurt, H., \& Icier, F. (2009). Ohmic and conventional heating of pomegranate juice: Effects on rheology, color, and total phenolics. Food Science and Technology International, 15(5), 503-512. https://doi.org/10.1177/ 1082013209350352

Yongsawatdigul, J., Park, J. W., Kolbe, E., Dagga, Y. A., \& Morrissey, M. T. (1995). Ohmic heating maximizes gel functionality of pacific whiting Surimi. Journal of Food Science, 60(1), 10-14. https://doi.org/10.1111/j.1365-2621.1995.tb05595.x
Yu, L. J., Ngadi, M., \& Raghavan, G. S. V. (2009). Effect of temperature and pulsed electric field treatment on rennet coagulation properties of milk. Journal of Food Engineering, 95(1), 115-118. https://doi.org/10.1016/j.jfoodeng.2009.04.013

Zhang, J.-J., Li, Y., Zhou, T., Xu, D.-P., Zhang, P., Li, S., \& Li, H.-B. (2016). Bioactivities and Health Benefits of Mushrooms Mainly from China. Molecules, 21(7), 938. https://doi.org/10.3390/molecules21070938

Zhang, L., Yu, G., Xia, D., \& Wang, J. (2019). Protein-protein interactions prediction based on ensemble deep neural networks. Neurocomputing, 324, 10-19. https://doi. org/10.1016/j.neucom.2018.02.097

Zhao, W., \& Yang, R. (2009). Effect of high-intensity pulsed electric fields on the activity, conformation and self-aggregation of pepsin. Food Chemistry, 114(3), 777-781. https://doi.org/10.1016/j.foodchem.2008.10.016

Zhao, W., \& Yang, R. (2010). Experimental study on conformational changes of lysozyme in solution induced by pulsed electric field and thermal stresses. Journal of Physical Chemistry B, 114(1), 503-510. https://doi.org/10.1021/jp9081189

Zhao, W., Yang, R., Lu, R., Tang, Y., \& Zhang, W. (2007). Investigation of the mechanisms of pulsed electric fields on inactivation of enzyme: Lysozyme. Journal of Agricultural and Food Chemistry, 55(24), 9850-9858. https://doi.org/10.1021/ jf072186s

Zhao, W., Yang, R., \& Zhang, H. Q. (2012). Recent advances in the action of pulsed electric fields on enzymes and food component proteins. Trends in Food Science \& Technology, 27(2), 83-96. https://doi.org/10.1016/j.tifs.2012.05.007

Zielińska, E., Baraniak, B., \& Karaś, M. (2018). Identification of antioxidant and antiinflammatory peptides obtained by simulated gastrointestinal digestion of three edible insects species (Gryllodes sigillatus, Tenebrio molitor, Schistocerca gragaria). International Journal of Food Science \& Technology, 53(11), 2542-2551. https://doi. org/10.1111/ijfs.13848

Zielińska, E., Karaś, M., Jakubczyk, A., Zieliński, D., \& Baraniak, B. (2018). Edible Insects as Source of Proteins (pp. 1-53). https://doi.org/10.1007/978-3-319-54528-8_67-1. 